\title{
New Caffeic Acid Phenylethyl Ester Analogs Bearing Substituted Triazole: Synthesis and Structure-Activity Relationship Study towards 5-Lipoxygenase Inhibition
}

\author{
Pierre-Philipe Roy, Diene Faye, Sébastien Blanchard, Marc Cormier, \\ Jérémie A. Doiron, Marc E. Surette, and Mohamed Touaibia \\ Department of Chemistry and Biochemistry, Université de Moncton, Moncton, NB, Canada E1A 3E9 \\ Correspondence should be addressed to Mohamed Touaibia; mohamed.touaibia@umoncton.ca
}

Received 27 February 2017; Accepted 9 April 2017; Published 4 May 2017

Academic Editor: Naoki Toyooka

Copyright ( 2017 Pierre-Philipe Roy et al. This is an open access article distributed under the Creative Commons Attribution License, which permits unrestricted use, distribution, and reproduction in any medium, provided the original work is properly cited.

\begin{abstract}
Leukotrienes are biosynthesized by the conversion of arachidonic acid by 5-Lipoxygenase and play a key role in many inflammatory disorders. Inspired by caffeic acid phenylethyl ester (CAPE) (2) and an analog carrying a triazole substituted by cinnamoyl and 5-LO inhibitors recently reported by our team, sixteen new CAPE analogs bearing substituted triazole were synthesized by copper catalyzed Huisgen 1,3-dipolar cycloaddition. Compound 10e, an analog bearing $p$-CF3 phenethyl substituted triazole, was equivalent to CAPE (2) but clearly surpassed Zileuton (2), the only approved 5-LO inhibitor. Substitution of the phenethyl moiety

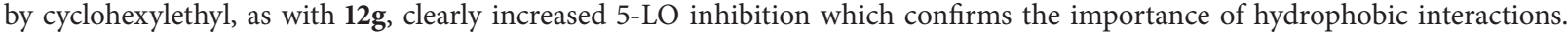
Molecular docking revealed new hydrogen bonds and $\pi-\pi$ interactions between the enzyme and some of the investigated compounds. Overall, this work highlights the relevance of exploring polyphenolic compounds as leukotrienes biosynthesis inhibitors.
\end{abstract}

\section{Introduction}

Leukotrienes (LTs) are a class of lipid mediators implicated in inflammatory responses [1]. In recent years, many studies have developed new pharmacological agent that influence the biosynthesis or action of LTs [2]. Despite their implication in inflammatory and allergic responses, LTs are also involved in many inflammatory diseases like asthma, arthritis, irritable bowel syndrome, and even cancer $[3,4]$.

5-Lipoxygenase (5-LO) is an enzyme that plays a crucial role for the formation of LTs as it catalyzes the first two steps of the conversion of arachidonic acid to the bioactive LTs [5]. Therefore, 5-LO is the preferred target for pharmaceutical control of LTs biosynthesis [2]. Moreover, the inhibition of 5$\mathrm{LO}$ is a validated target for the treatment of asthma $[6,7] .5-$ LO inhibitors have also shown promising results in blocking the proliferation of several tumors cell lines $[8,9]$.

Recently, caffeic acid phenethyl ester (CAPE, 1) (Figure 1) was found to be a potent 5 -LO inhibitor [10-12] by our research group. Many studies reported by our laboratory have also shown the potential of CAPE and its analogs as potential anti-inflammatory compounds.

Contrary to the belief that polyphenols inhibit 5-LO exclusively through their antioxidant properties, our previous results clearly show that the presence or absence of specific functional groups influences 5-LO inhibition independent of their impact on antioxidant activity $[10,11]$. Structural modifications which resulted from changes in the ester structure showed significantly improved inhibition of 5-LO when compared to Zileuton (2) [13], the only clinically available 5-LO inhibitor. However, Zileuton (2) was shown to have hepatotoxic effects, low potency, and short half-life [14]; therefore research continues for the development of new 5LO inhibitors.

In a previous work, an analog of caffeic acid bearing a triazole (compound 3, Figure 1) emerged as the best inhibitor of a series of analogs with 1 to 6 caffeoyl moieties [15]. Further structure-activity relationship was performed later where 
<smiles>O=C(/C=C/c1ccc(O)c(O)c1)OCCc1ccccc1</smiles><smiles>O=C(/C=C/c1ccc(O)c(O)c1)OCCn1cc(COC(=O)/C=C/c2ccccc2)nn1</smiles><smiles>CC(c1cc2ccccc2s1)N(O)C(N)=O</smiles>

Zileuton (2)<smiles>COc1ccc(/C=C/C(=O)O[Hg]c2cn(CCCO)nn2)cc1OC</smiles>

(4) $[17]$

Figure 1: Structures of CAPE (1), Zileuton (2), compound (3) [15], and compound 4 [13].<smiles>[R]c1ccc(CCn2cc(COC(=O)/C=C/c3ccc(O)c(O)c3)nn2)cc1</smiles>

Figure 2: Caffeic acid phenylethyl ester analogs bearing substituted triazole designed in this study.

different triazoles containing cinnamic acid and caffeic acid analogs were investigated for 5-LO inhibition [16]. De Lucia also synthesized additional analogs [13] related to compound 3. Interestingly, they found that the length of the linker was critical for the activity of the molecule; a longer linker had better inhibition capacity [13]. While the importance of the linker length is now relatively established, it is not clear if the triazole needs to be far away from the caffeic acid moiety and which type of substitution on the triazole moiety will impact the 5-LO inhibition. It is also noteworthy that the mechanism of inhibition of 5-LO by these CAPE analogs bearing substituted triazole analogs is not well established [16, 17]. Moreover, structure-activity relationship studies (SAR) are required to learn more about the potential mode of action of these molecules.

In the present study, we describe the design and synthesis of new caffeic acid phenylethyl ester analogs bearing substituted triazole derived from compound 3 (Figure 2). With these analogs, the effect of the substitution of the triazole moiety by a phenyl as well as the linker length between the latter and triazole was investigated. The substitution of the phenyl with electron-withdrawing and electron-donating groups was also explored.

Finally, the substitution of the triazole with various allyl groups of various sizes was also investigated. After anti-LTs activity screening in a HEK293 cell model, 5-LO inhibition potential of selected compounds was determined in human polymorphonuclear leukocytes (PMNL). Moreover, a molecular docking study was conducted to shine a new light on the mechanism of inhibition of these compounds.

\section{Results and Discussion}

2.1. Chemistry. To investigate the structure-activity relationship of compound $\mathbf{3}$, closely related analogs were synthesized. We examined the molecular interaction that would have an effect on 5-LO inhibition by linking with the Huisgen 1,3dipolar cycloaddition (commonly known as "click reaction") reaction different molecular groups on the caffeoyl moiety. All analogs were synthesized by an efficient sequential procedure that directly links the azides, which can be potentially explosive, obtained from the commercially available organic halides to the alkyne moiety of the caffeic propargylic ester.

As shown in Scheme 1, a first series of analogs was synthesized to examine the effect of the length of the linker between the triazole core and a nonsubstituted phenyl moiety.

Sequential synthesis of the appropriate organic azide synthesized from the commercially available organic halides $(7 \mathbf{a}-\mathbf{c})$ followed by the copper catalyzed 1,3-dipolar cycloaddition of these azides with (6) provided analogs $8 \mathbf{a}-\mathbf{8 c}$ with one to three methylenes between the triazole and the nonsubstituted phenyl moiety in moderate yield (Scheme 1).

To investigate the effect of substitution of the phenyl of series 1 with electron-withdrawing and electron-donating groups, new analogs were designed as shown in Scheme 2. As compounds 8a-b were essentially equipotent with Zileuton (2) and compound (3) (see results of LT inhibition below), analogs of $\mathbf{8 b}$ with substituted phenyl were designed and synthesized. It should also be mentioned that the accessibility of the various halogenated derivatives with two methylenes allowed us to make this series more easily 


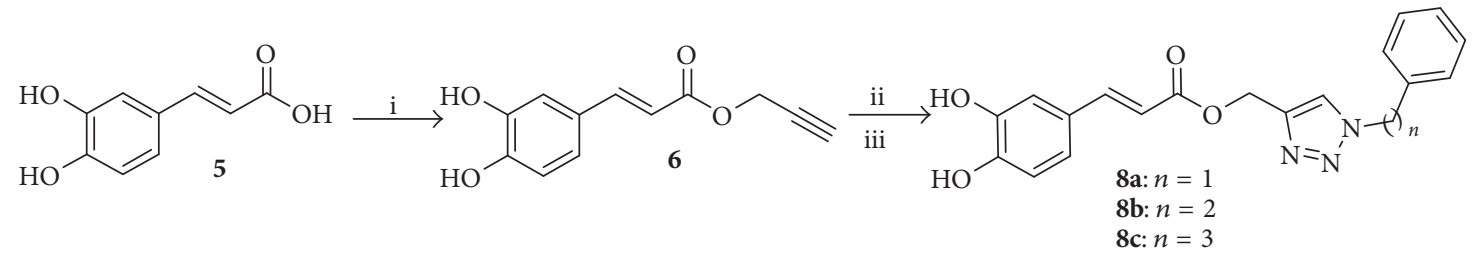

Scheme 1: Synthesis of series 1: (i): propargyl bromide, $\mathrm{Na}_{2} \mathrm{CO}_{3}$, KI, HMPA, $0^{\circ} \mathrm{C}$-rt, overnight, $43 \%$; (ii): appropriate aryl bromide (7a-c), $\mathrm{NaN}_{3}$, DMSO, rt, overnight; (iii): 6, $\mathrm{CuSO}_{4} \cdot 5 \mathrm{H}_{2} \mathrm{O}$, sodium ascorbate, $\mathrm{H}_{2} \mathrm{O}$, rt, overnight (8a: $42 \%$; 8b: $57 \%$; 8c: $53 \%$ ).<smiles>[R]c1ccc(CCBr)cc1</smiles><smiles>[R]c1ccc(CCn2cc(COC(=O)/C=C/c3ccc(O)c(O)c3)nn2)cc1</smiles>

10a: $\mathrm{R}=\mathrm{CH}_{3}$, 10b: $\mathrm{R}=\mathrm{OCH}_{3}$ 10c: $\mathrm{R}=\mathrm{F}$ 10d: $\mathrm{R}=\mathrm{OH}$ 10e: $\mathrm{R}=\mathrm{CF}_{3}$ 10f: $\mathrm{R}=\mathrm{NO}_{2}$

Scheme 2: Synthesis of series 2: (i): $\mathrm{NaN}_{3}$, DMSO, rt, overnight; (ii) 6, $\mathrm{CuSO}_{4} \cdot 5 \mathrm{H}_{2} \mathrm{O}$, sodium ascorbate, $\mathrm{H}_{2} \mathrm{O}$, rt, overnight (10a: $65 \%$; 10b: 65\%; 10c: 63\%; 10d: 47\%; 10e: 68\%; 10f: 53\%).<smiles>[R][Y]([H])C1C[C]1[R]</smiles>

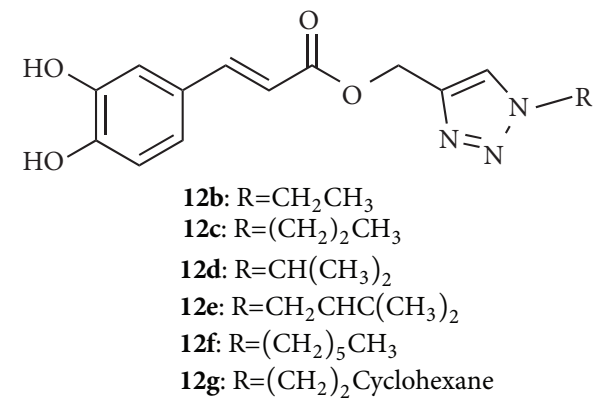

Scheme 3: Synthesis of series 3: (i): 6, $\mathrm{NaN}_{3}$, MeI, CuI, acetone/ $\mathrm{H}_{2} \mathrm{O}(1 / 1)$, rt, ultrasound, overnight (12a: 24\%). (ii): $\mathrm{NaN}_{3}$, DMSO, rt, overnight; (iii): 6, $\mathrm{CuSO}_{4} \cdot 5 \mathrm{H}_{2} \mathrm{O}$, Sodium ascorbate, $\mathrm{H}_{2} \mathrm{O}$, rt, overnight (12b: 59\%; 12c: 55\%; 12d: 54\%; 12e: 63\%; 12f: 22\%; 12g: 51\%).

following our sequential procedure (Scheme 2). Copper catalyzed 1,3-dipolar cycloaddition of substituted phenethyl azides obtained from the corresponding bromide analogs $(9 \mathbf{a}-\mathbf{f})$ with compound $\mathbf{6}$ provided analogs 10a-f with electron-withdrawing and electron-donating substituents on the phenyl moiety (Scheme 2).

To investigate the effect of the presence of hydrophobic carbon chains, a third series of analogs was designed. In this series, the triazole was substituted by various alkyls, from the simpler (methyl) to branched alkyls. As shown in Scheme 3 and following our sequential procedure, analogs $(\mathbf{1 2 b}-\mathbf{g})$ containing various alkyl groups linked to the triazole were synthesized. Compound 12a could not be obtained using the same method. This is probably due to the gaseous nature of methyl azide. Therefore, another method was used to obtain the methyl-substituted triazole analog (12a). With a one-pot procedure, we were able to obtain the desired methyl-substituted triazole by copper catalyzed 1,3-dipolar cycloaddition of the methyl azide, formed in situ by the substitution reaction of methyl iodine and sodium azide, with the caffeic propargylic ester 6 (Scheme 3).

\subsection{Biological Evaluation}

2.2.1. Inhibition of 5-LO Products Synthesis in Whole HEK293 Cells. Inhibition of leukotriene biosynthesis was assayed in intact HEK293 cells that are stably transfected with human 5LO. This model serves as a highly reproducible model of 5-LO product biosynthesis in which compounds can be preliminarily screened for anti-LTs activity before moving on to more complex systems [11]. All compounds were assayed at $1 \mu \mathrm{M}$, including known inhibitors CAPE (1) and Zileuton (2) whose inhibitory potencies were used as reference points (Figure 3 ). As shown in Figure 3, analogs 8a-c having one- to threemethylene linker between the triazole and the nonsubstituted phenyl moiety are equivalent to Zileuton but remain less active than CAPE (1). Analog 8c, with three-methylene linker, is the most active of the three compounds with an inhibition at around $50 \%$, which clearly surpasses Zileuton (2). The small difference in lipophilicity between these molecules can probably explain the small difference in activity.

In order to investigate the effect of substitution of the $\mathbf{8 b}$ benzylic ring, analogs with electron-withdrawing 


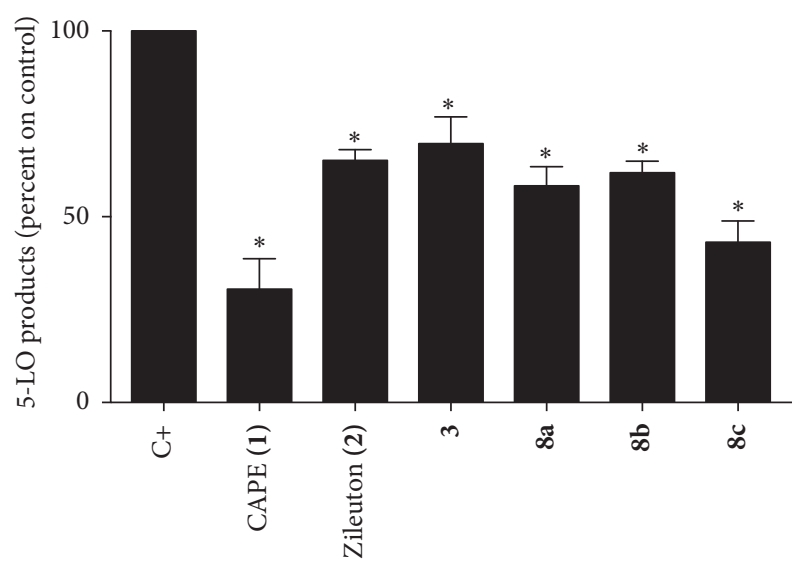

Test compound $(1 \mu \mathrm{M})$

FIGURE 3: Inhibition of 5-LO products synthesis by analogs $(\mathbf{8 a - c})$ in whole HEK293 cells. Values are the means \pm SEM of three independent experiments, each performed in quadruplicate; ${ }^{*}$ different from control (diluent) as determined by one-way ANOVA with Dunnett's multiple comparison test $(p<0.05)$.

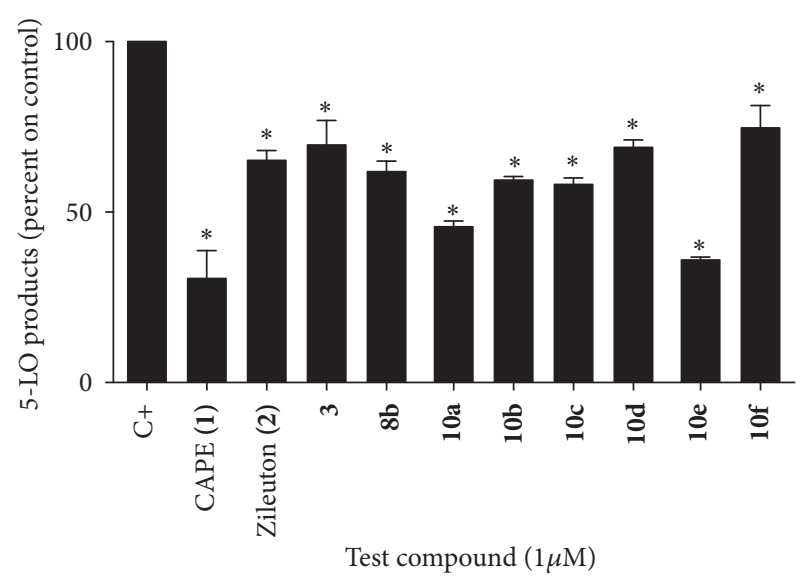

FIGURE 4: Inhibition of 5-LO products synthesis by $\mathbf{1 0 a}-\mathbf{f}$ in whole HEK293 cells. Values are the means \pm SEM of three independent experiments, each performed in quadruplicate; ${ }^{*}$ different from control (diluent) as determined by one-way ANOVA with Dunnett's multiple comparison test $(p<0.05)$.

and electron-donating substituents were tested as shown in Figure 4. All analogs were either equivalent to CAPE (1) and analog 3 or significantly more active than Zileuton (2). As shown in Figure 4, the substitution of the phenyl in the para position with methyl, a weak donating substituent, seems to have a positive impact on 5-LO inhibition which was increased by almost $20 \%$. The effect of the hydrophobic substituent seems to be decisive for increasing the inhibition of 5-LO.

The introduction in the para position of the phenyl moiety of moderate $\left(-\mathrm{OCH}_{3}\right.$ and $\left.-\mathrm{F}\right)$ or even strong $(-\mathrm{OH})$ donating groups appears to have a moderate effect on activity since the inhibitory activity of $\mathbf{1 0 b}-\mathbf{d}$ is equivalent to that of $\mathbf{8 b}$. On the other hand, the substitution of phenyl by weak electron-withdrawing substituent seems to be very favorable

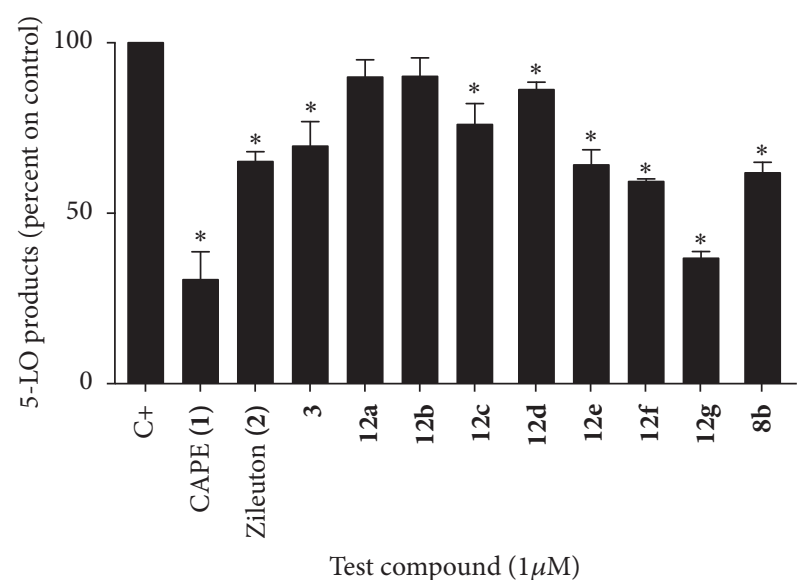

FIGURE 5: Inhibition of 5-LO products synthesis by $12 \mathbf{a}-\mathbf{c}$ and $\mathbf{8 b}$ in whole HEK293 cells. Values are the means \pm SEM of three independent experiments, each performed in quadruplicate; * different from control (diluent) as determined by one-way ANOVA with Dunnett's multiple comparison test $(p<0.05)$.

for 5-LO inhibition; the induction of $-\mathrm{CF}_{3}$ analog increases the inhibitory capacity of $\mathbf{8 b}$ by almost $30 \%$. Compound 10e is equivalent to CAPE (1) but clearly surpasses the Zileuton (2) (Figure 4). The difference of lipophilicity is not as important in explaining the difference of 5-LO inhibition of $\mathbf{8 b}, \mathbf{1 0 a}$, and 10e; an electronic effect associated with favorable interactions due to the presence of fluorine atoms can explain this difference.

It would have been supposed that the accentuation of the deactivating effect on phenyl by strong withdrawing substituents such as nitro group could increase the activity even more. However, as shown in Figure 4, the substitution of phenyl with a nitro considerably reduces the effect of $\mathbf{1 0 f}$, which becomes less active than 10e. Analog 10 f was even less potent than the unsubstituted analog $\mathbf{8 b}$ (Figure 4).

In order to investigate the presence of a hydrophobic group, hydrophobic chains of different sizes and degrees of substitution were tested in the third series. As shown in Figure 5, some molecules were significantly less active than CAPE (1), Zileuton (2), and analog 3. Analogs 12e and 12f were equivalent to Zileuton (2) and analog 3 . Analog $12 \mathrm{~g}$ was the most active of the whole while being also much more active than the Zileuton and the analog 3.

Substitution of triazole with methyl, as in $\mathbf{1 2 a}$, or two- to three-carbon alkyl chain (12b and 12c), was not conducive to good inhibition of 5-LO. Substitution of triazole with a more substituted three-carbon alkyl chain such as an isopropyl (analog 12d) or a substituted alkyl chain with a less flexible end, such as 3-methylbut-2-enyl (analog 12e), does not seem to be favorable for 5-LO inhibition. Substitution of the triazole with a hexyl chain slightly increases the 5-LO inhibition. As shown in Figure 5, analog 12f, bearing the hexyl chain, was more active than 12a but equivalent to $\mathbf{8 b}$, the analog with triazole substituted with phenethyl. Substitution of the triazole with cyclohexylethyl was very favorable for the inhibition of 5-LO as shown in Figure 5. 


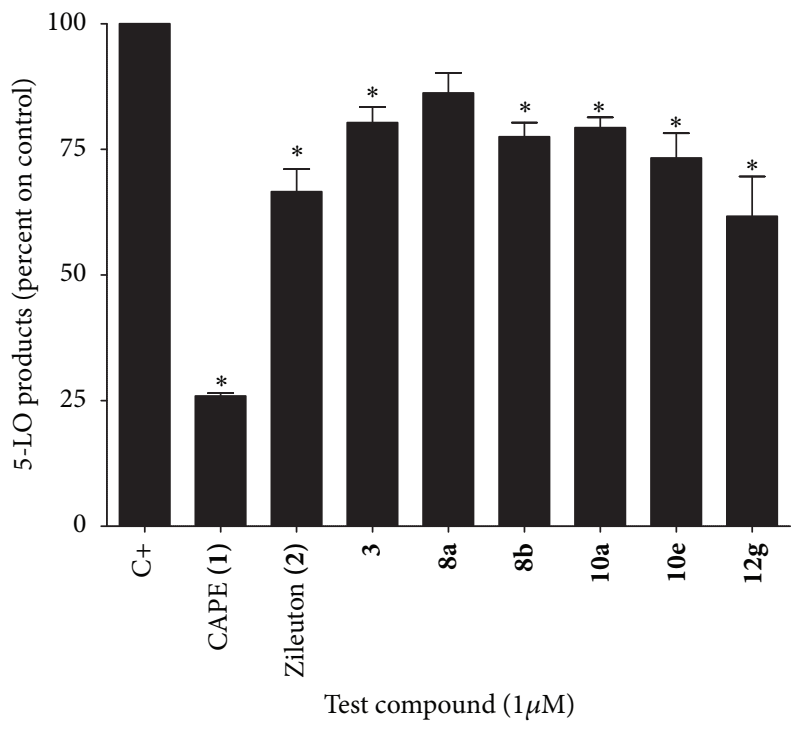

Figure 6: Inhibition of 5-LO products synthesis by analogs 8ab, 10a, 10e, and $12 \mathrm{~g}$ in stimulated human PMNL. Values are the means \pm SEM of three independent experiments, each performed in quadruplicate; ${ }^{*}$ different from control (diluent) as determined by one-way ANOVA with Dunnett's multiple comparison test $(p<$ $0.05)$.

Favorable interactions of the cyclohexylethyl moiety can explain this good activity since the molecule was significantly more active than Zileuton (2). Analog $12 \mathrm{~g}$ was also more active than analogs $\mathbf{1 2 f}$ and $\mathbf{8 b}$ having substituted triazole with hexyl or phenethyl, respectively (Figure 5 ). The difference in lipophilicity can not explain this difference since the estimated Logp of the three molecules $(\mathbf{8 b}, \mathbf{1 2 f}$, and $\mathbf{1 2 g})$ was very close.

\subsubsection{Inhibition of 5-LO Products in Simulated Human PMNL.}

To further probe inhibitory activity of lead compounds selected from preliminary HEK293 screenings (Figures 3, 4, and 5), 5-LO inhibition assays were undertaken in stimulated human PMNL in the presence of $1 \mu \mathrm{M}$ of inhibitors. 5-LO is highly expressed in PMNL and these cells are important physiological producers of $\mathrm{LTB}_{4}[11,18]$.

As shown in Figure 6, analogs $\mathbf{8 a}$ and $\mathbf{8 b}$ having a triazole substituted by benzyl or ethynylphenyl were less active than CAPE (1) but were equivalent to Zileuton (2) and analog 3. Bearing an ethenylcyclohexyl-substituted triazole, $\mathbf{1 2 g}$ was the best inhibitor of the selected molecules. $12 \mathrm{~g}$ was more active than its analogs $3,10 \mathrm{a}$, and $10 \mathrm{~b}$ which have methyl- or trifluoromethyl-substituted triazole, respectively.

Analog $12 \mathrm{~g}$ was also equivalent to Zileuton (2) but remains less active than CAPE (1); the favorable effect of the presence of the cyclohexylethyl moiety seems to be confirmed in the PMNL test. The difference in inhibitory activity of our molecules in HEK293 cells and in stimulated human PMNL may reflect the availability or cell permeation of our inhibitors. The substitution of the terminal phenyl group in CAPE (1) with monosubstituted triazoles leads to a loss of activity in PMNL at $1 \mu \mathrm{M}$. Moreover, while 10e is more lipophilic than $\mathbf{1 2 g}$, the three fluorine atoms and the aromatic ring may form hydrogen bonds or $\pi-\pi$ interactions that could diminish the availability and/or cell permeability. Furthermore, Van der Waals interaction of the cyclohexylethyl moiety of $\mathbf{1 2 g}$ seems to be favorable for 5-LO inhibition as $12 \mathrm{~g}$ was the best inhibitor and was equipotent to Zileuton (2).

2.3. Molecular Docking. All designed and synthesized compounds were docked to 5-LO in this study. From the obtained docking results, the binding energy was determined for each ligand as well as hydrogen bonds, interactions, and coordination (Table 1). Molecular docking was performed on a modified 5-LO protein (PDB code: $3 \mathrm{O} 8 \mathrm{Y}$ ).

Analogs 8b-c, 10a-d, and $12 \mathrm{~g}$ were almost overlaid with slight shifts in position for the $\mathrm{R}$ group. The catechol group was positioned near the iron atom and its coordinating residues while the other extremity of the ligand was located near the end of the cavity, near His600. This group seems to have the best classed analogs (Table 1).

As shown in Figure 7, it is interesting to see the proximity/interaction of the cyclohexyl moiety of analog $12 \mathrm{~g}$ with several amino acids of the protein, in particular with Tyr181 Al603 and Asn425. This proximity/interaction can explain the favorable effect of the presence of this group observed in the inhibition tests of 5-LO with 12g in HEK293 and PMNL cells (Figures 5 and 6). Comparison of the results of the modeling of analogs $\mathbf{1 2 g}$ and $\mathbf{8 b}$ clearly shows that hydrophobic interactions and the cyclohexyl flexibility appear to be crucial for 5-LO inhibition.

Analogs 8a, 10e-f, and 12e-f differ, in some minor way, from the previous group. For $10 \mathbf{e}-\mathbf{f}$, the catechol was perpendicular compared to the previous molecules. $12 \mathrm{f}$ takes a more direct route due to its short length.

Analogs 12b-d were overlaid; only the R group differed slightly. This group has the characteristic of being inverted compared to the previous molecules, having the catechol section near the end of the cavity while the $\mathrm{R}$ group is near the iron atom. It does keep the same general overlap even if inverted. This group seems to have the least stable ligand.

CAPE (1) analogs 3 and $\mathbf{4}$ differ in their positioning. In general, they take similar positions to the previous group. Analog 4, due to its long length, must contort much more to fit inside the cavity and reaches the furthest it can in both extremities. It also presents the triazole ring (nitrogen atoms side) to the iron atom compared to the R group for previous ligands. CAPE's (1) shorter length and position make it so that it cannot reach the iron atom. Analog 3 presents its second ester to the iron atom instead of presenting a triazole.

Analog 12a was shifted slightly deeper inside the cavity due to its shorter length, meaning that the R group was placed near the end of the cavity and the catechol group does not reach the section of the cavity containing the iron atom. Its position resembles more Zileuton (2) than the other analogs. Similarly, both Zileuton (2) enantiomers occupy the end of the cavity and do not reach the iron containing section of the cavity.

In most cases, the tested ligands seem to fill most of the cavity. 12a seems to leave a slightly more open space than the 
TABLE 1: Molecular modeling data*

\begin{tabular}{|c|c|c|c|c|}
\hline Molecule & $\begin{array}{c}\text { Affinity } \\
\text { (kcal/mol) }\end{array}$ & Hydrogen bonds & $\pi-\pi$ interactions & Coordination \\
\hline $10 \mathrm{e}$ & -9.1 & Asn554 & Phe177, His367 × 2 & $\mathrm{Fe} 2 \times 2$ \\
\hline $10 \mathrm{c}$ & -8.6 & - & His367, Phe421 & $\mathrm{Fe} 2$ \\
\hline CAPE (1) & -8.5 & - & His372 & - \\
\hline $8 b$ & -8.4 & - & His367, Phe421 & $\mathrm{Fe} 2$ \\
\hline $8 c$ & -8.4 & - & His367, Phe421 & $\mathrm{Fe} 2$ \\
\hline $4[17]$ & -8.4 & - & His372 & $\mathrm{Fe} 2 \times 2$ \\
\hline $10 \mathrm{f}$ & -8.4 & Leu607 & Phe177, His367 × 2 & $\mathrm{Fe} 2 \times 2$ \\
\hline $10 \mathrm{a}$ & -8.4 & - & His367, Phe421 & $\mathrm{Fe} 2$ \\
\hline $12 \mathrm{~g}$ & -8.4 & - & His367, Phe421 & $\mathrm{Fe} 2$ \\
\hline $12 a$ & -8.3 & - & His372 & - \\
\hline 10d & -8.2 & Ile673 & His367, Phe421 & $\mathrm{Fe} 2$ \\
\hline $8 \mathbf{a}$ & -8.1 & Tyr181 & His600 & $\mathrm{Fe} 2$ \\
\hline $10 \mathrm{~b}$ & -8.1 & - & His367, Phe421 & $\mathrm{Fe} 2$ \\
\hline $12 b$ & -8.0 & - & His367, Phe421 & - \\
\hline $12 d$ & -8.0 & - & His367 & - \\
\hline $12 \mathrm{e}$ & -8.0 & Tyr181 & Phe421 & - \\
\hline $12 \mathrm{f}$ & -7.9 & - & Phe177, His367 & $\mathrm{Fe} 2$ \\
\hline $12 c$ & -7.9 & - & His367, Phe421 & - \\
\hline $3[15]$ & -7.6 & - & Phel77 & $\mathrm{Fe} 2$ \\
\hline (R)-Zileuton (2) & -6.6 & Leu $420 \times 2$ & Phe421 & - \\
\hline (S)-Zileuton (2) & -6.5 & - & - & - \\
\hline
\end{tabular}

${ }^{*}$ Molecular docking was performed on a modified 5-LO protein (PDB code: $3 \mathrm{O} 8 \mathrm{Y}$ ). Figure 7 showing the double bond in " $Z$ "-form is a result of the software used to generate the $2 \mathrm{D}$ image, LigPlot. The file given by the molecular docking software has the " $E$ "-form conserved.

others while analog 4 seems to fill the cavity particularly well. Zileuton (2) fills the end of the cavity while leaving the area near the iron atom open due to its shorter length.

In agreement with what was previously said, Zileuton (2) and the first series have similar affinity, with the first series being favored compared to Zileuton (2). For the second series, the tendency seems to also agree except for $\mathbf{1 0} \mathrm{c}$ and $\mathbf{1 0 f}$ being slightly more stable than what would be expected when compared to the inhibitory potential. For the third series, the results seem to differ more than the previous series. For analog $12 \mathrm{~g}$ and to some extent $\mathbf{1 2 f}$, the affinity seems to be less stable than what would be expected.

When looking at the interactions made by the most stable ligands or that have the strongest measured inhibition, it seems that a $\pi-\pi$ interaction with either His 367 or His 372 is helpful. Both are iron coordinating residues [19]. It also seems that not doing a metal coordination with the iron atom is detrimental to both its affinity and measured activity.

\section{Conclusion}

Despite its undesirable effects, particularly its hepatotoxicity, Zileuton is still the only approved 5-LO inhibitor for clinical use to date. In this study, sixteen new 5-LO inhibitors derived from CAPE (1) and compound 3, recently reported by our team, were synthesized, characterized, and tested for their potential to inhibit 5-LO in both HEK293 and stimulated human PMNL cells. Analog 12g, bearing an ethenylcyclohexyl-substituted triazole, was the best inhibitor of all the series. Analog 12g was also equipotent to Zileuton (2) but remains less active than CAPE (1). The favorable effect of the presence of the cyclohexylethyl moiety seems to be confirmed in the PMNL test. Hydrophobic interactions appear to be crucial for good inhibition of 5-LO as shown by compound 12g. Overall, this work highlights novel compounds with interesting properties against 5-LO and further exemplifies the likely importance of exploring the impact of polyphenolic compounds as leukotriene biosynthesis inhibitors.

\section{Experimental Section}

4.1. Methods and Materials. All chemicals used were purchased from Aldrich (CA). Purification of compounds was carried out by flash chromatography (CombiFlash ${ }^{\circledR}$, Separation System SG 100C, ISCO) or by silica gel circular chromatography (chromatotron ${ }^{\circledR}$, model 7924, Harrison Research). TLC was run on silica gel coated aluminum sheets (SiliaPlate TLC, Silicycle ${ }^{\circledR}$ ) with detection by UV light (254 nm, UVS-11, Mineralight ${ }^{\circledR}$ shortwave UV lamp). Melting points were obtained using a MELTEMP (model 1001D) melting point apparatus. FTIR spectra were recorded on a Cary 630 FTIR spectrometer equipped with a single reflection diamond ATR. NMR spectra were recorded on a Bruker $^{\circledR}$ Avance III $400 \mathrm{MHz}$ spectrometer. High-resolution 


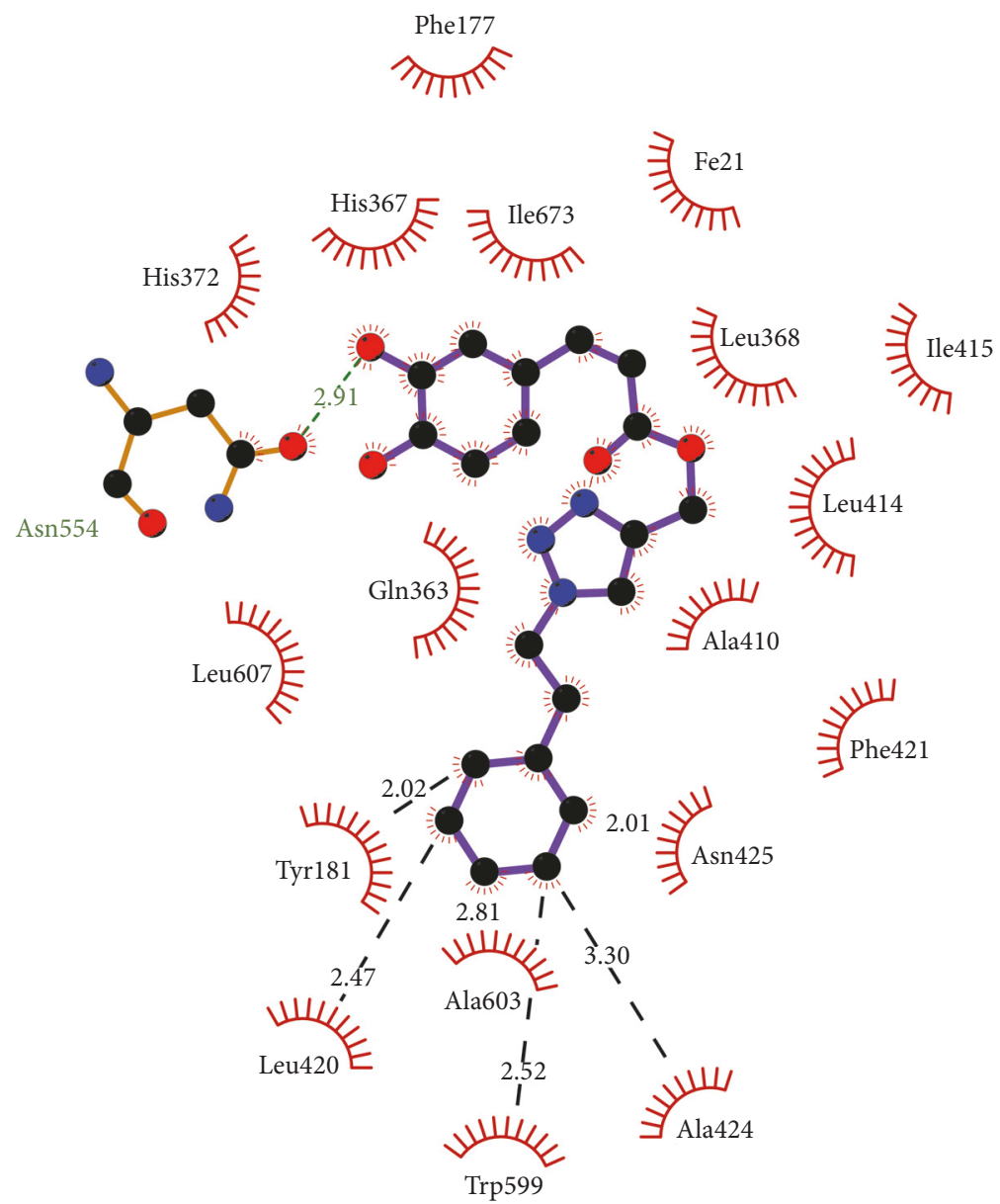

FIgURE 7: Molecular docking results of $\mathbf{1 2} \mathbf{g}$ displayed in LigPlot.

mass measurements were performed on a Bruker Daltonics' micrOTOF instrument in positive or negative electrospray.

2-Propynyl (E)-3-(3,4-dihydroxyphenyl)acrylate 6. To a solution of caffeic acid (1 g, $5.61 \mathrm{mmol})$ in $5 \mathrm{ml}$ of hexamethylphosphoramide (HMPA) under argon atmosphere 1.2 equivalent of $\mathrm{Na}_{2} \mathrm{CO}_{3}(698.5 \mathrm{mg}, 6.59 \mathrm{mmol})$ is added and the solution is stirred at $0^{\circ} \mathrm{C}$ for an hour. Then a solution of propargyl bromide in $1 \mathrm{ml}$ of HMPA is added to the solution in a span of $30 \mathrm{~min}$. A catalytic amount of $\mathrm{KI}$ is added to the solution and the mixture was stirred overnight. The reaction mixture is then poured in ice. The solution is extracted 3 times by ethyl acetate; then the aqueous phase is neutralized by a solution of $\mathrm{HCl} 1 \mathrm{M}$ and extracted one last time with EtOAc. The combined organic phase is washed three times with brine, dried with $\mathrm{MgSO}_{4}$, and concentrated under vacuum to afford the crude product. Compound $\mathbf{6}$ was obtained as a white solid is obtained after flash chromatography (EtOAc/Hexane 20:80). Yield: $528 \mathrm{mg}(43 \%) ; R_{f}=0.57$ (EtOAc/hexane 50:50); m.p. $=133-135^{\circ} \mathrm{C}$; IR $\left(\nu\left(\mathrm{cm}^{-1}\right)\right)$ : 3503-3479 ( $\left.\mathrm{C}_{\mathrm{ar}} \mathrm{O}-\mathrm{H}\right), 3270\left(\mathrm{C}_{\mathrm{sp}}-\mathrm{H}\right), 2100(\mathrm{C} \equiv \mathrm{C}), 1683(\mathrm{C}=\mathrm{O})$, 1629-1440 (C=C), 1290, 1162 (C-O); ${ }^{1} \mathrm{H}$ NMR $(400 \mathrm{MHz}$, DMSO-d $\left.\mathrm{d}_{6}, 25^{\circ} \mathrm{C}\right), \delta$ (ppm): $9.66\left(\mathrm{~s}, 1 \mathrm{H}, \mathrm{C}_{\mathrm{ar}} \mathrm{OH}\right), 9.18(\mathrm{~s}, 1 \mathrm{H}$, $\left.\mathrm{C}_{\mathrm{ar}} \mathrm{OH}\right), 7.55-7.51\left(\mathrm{~d}, 1 \mathrm{H}, J=15.9 \mathrm{~Hz},=\mathrm{CHC}_{\mathrm{ar}}\right), 7.08-7.02(\mathrm{~m}$, $\left.2 \mathrm{H}, \mathrm{H}_{\mathrm{ar}}\right), 6.79-6.77\left(\mathrm{~m}, 1 \mathrm{H}, \mathrm{H}_{\mathrm{ar}}\right), 6.33-6.29(\mathrm{~d}, 1 \mathrm{H}, J=15.9 \mathrm{~Hz}$, $=\mathrm{CHCO}), 4.80-4.79\left(\mathrm{~d}, 2 \mathrm{H}, J=2.44 \mathrm{~Hz}, \mathrm{OCH}_{2} \mathrm{C}\right), 3.55-3.54$ $(\mathrm{t}, 1 \mathrm{H}, J=1.80 \mathrm{~Hz}, \mathrm{CCH}) ;{ }^{13} \mathrm{C}$ NMR $\left(100 \mathrm{MHz}, \mathrm{DMSO}-\mathrm{d}_{6}\right.$, $\left.25^{\circ} \mathrm{C}\right), \delta$ (ppm): 166.23, 149.14, 146.61, 146.05, 125.82, 122.15, $116.20,115.39,113.40,79.21,77.97,51.93$; HRMS $m / s$ calc. for $\mathrm{C}_{12} \mathrm{H}_{10} \mathrm{O}_{4}+\left(\mathrm{H}^{+}\right): 219.0652$; found: 219.0651 .

4.1.1. General Procedure for the Preparation Compounds $8 a-8 c, 10 a-10 f$, and $12 b-12 h$. To a solution of the appropriate halide (7a-c, $9 \mathbf{a}-\mathbf{f}$ or $\mathbf{1 1 b}-\mathbf{h})$ in $2 \mathrm{ml}$ of DMSO $\mathrm{NaN}_{3}$ is added and the solution was stirred overnight. Then, $\mathbf{6}$, $\mathrm{CuSO}_{4} \cdot 5 \mathrm{H}_{2} \mathrm{O}(0.2 \mathrm{eq})$, sodium ascorbate $(0.10 \mathrm{eq})$, and $2 \mathrm{ml}$ of distilled water are added to the solution and the solution was stirred overnight. The solution is diluted in water and the mixture is extracted 3 times with EtOAc. The combined organic phase is washed twice with a solution of $\mathrm{NH}_{4} \mathrm{Cl}$ $5 \mathrm{M}$ and then twice with brine. The combined organic phase is dried with $\mathrm{MgSO}_{4}$, to afford the crude product. The purification was performed as stated for each compound.

(1-Benzyl-1H-1,2,3-triazol-4-yl)methyl(E)-3-(3,4-dihydroxyphenyl)acrylate 8a. Benzyl bromide (7a) (54.43 $\mu \mathrm{l}$, $0.46 \mathrm{mmol}$ ), $\mathrm{NaN}_{3}$ (33.61 mg, $\left.0.52 \mathrm{mmol}\right), 6$ (118.59 mg, $0.54 \mathrm{mmol}), \quad \mathrm{CuSO}_{4} \cdot 5 \mathrm{H}_{2} \mathrm{O} \quad(53.59 \mathrm{mg}, 0.21 \mathrm{mmol})$, and 
sodium ascorbate $(10.38 \mathrm{mg}, 0.052 \mathrm{mmol})$. A beige solid is obtained after flash chromatography (EtOAc/hexane $50: 50$ ). Yield: $79.4 \mathrm{mg}$ (42\%); $R_{f}=0.14$ (EtOAc/hexane 50:50); m.p. $=152-153^{\circ} \mathrm{C}$; IR $\left(\nu\left(\mathrm{cm}^{-1}\right)\right): 3300-3000\left(\mathrm{C}_{\mathrm{ar}} \mathrm{O}-\mathrm{H}\right), 1687$ $(\mathrm{C}=\mathrm{O}), 1630-1443$ (C=C), 1280, 1179 (C-O); ${ }^{1} \mathrm{H}$ NMR (4000 MHz, DMSO-d $\left.{ }_{6}, 25^{\circ} \mathrm{C}\right), \delta(\mathrm{ppm}): 9.63$ (s, $\left.1 \mathrm{H}, \mathrm{C}_{\mathrm{ar}} \mathrm{OH}\right)$, $9.15\left(\mathrm{~s}, 1 \mathrm{H}, \mathrm{C}_{\mathrm{ar}} \mathrm{OH}\right), 8.24(\mathrm{~s}, 1 \mathrm{H},=\mathrm{CHN}), 7.51-7.48(\mathrm{~d}, 1 \mathrm{H}, J=$ $\left.15.8 \mathrm{~Hz},=\mathrm{CHC}_{\mathrm{ar}}\right), 7.41-7.32\left(\mathrm{~m}, 5 \mathrm{H}, \mathrm{H}_{\mathrm{ar}}\right), 7.05-7.00(\mathrm{~m}, 2 \mathrm{H}$, $\left.\mathrm{H}_{\mathrm{ar}}\right), 6.77-6.75\left(\mathrm{~m}, 1 \mathrm{H}, \mathrm{H}_{\mathrm{ar}}\right), 6.30-6.26(\mathrm{~d}, 1 \mathrm{H}, J=15.9 \mathrm{~Hz}$, $=\mathrm{CHCO}), 5.61\left(\mathrm{~s}, 2 \mathrm{H},-\mathrm{OCH}_{2}-\right), 5.22\left(\mathrm{~s}, 2 \mathrm{H},-\mathrm{NCH}_{2} \mathrm{C}_{\mathrm{ar}}\right) ;{ }^{13} \mathrm{C}$ NMR (100 MHz, DMSO-d $\left.{ }_{6}, 25^{\circ} \mathrm{C}\right), \delta$ (ppm): 166.73, 149.00, $146.18,146.02,142.85,136.42,129.25,128.65,128.50,125.87$, $125.32,121.99,116.17,115.36,113.88,57.46,53.29$; HRMS m/s calc. for $\mathrm{C}_{19} \mathrm{H}_{17} \mathrm{~N}_{3} \mathrm{O}_{4}+\left(\mathrm{H}^{+}\right)$: 352.1292; found: 352.1289 .

(1-Phenethyl-1H-1,2,3-triazol-4-yl)methyl (E)-3-(3,4-dihydroxyphenyl)acrylate $\mathbf{8 b}$. (2-Bromoethyl)benzene (7b) (65 $\mu \mathrm{l}$, $0.48 \mathrm{mmol}$ ), $\mathrm{NaN}_{3}$ (37.97 mg, $\left.0.58 \mathrm{mmol}\right), 6$ (107.76 mg, $0.49 \mathrm{mmol}), \mathrm{CuSO}_{4} \cdot 5 \mathrm{H}_{2} \mathrm{O}(45 \mathrm{mg}, 0.18 \mathrm{mmol})$, and sodium ascorbate $(16.20 \mathrm{mg}, 0.082 \mathrm{mmol})$. A beige solid is obtained after flash chromatography (EtOAc/hexane 50:50). Yield: $102.4 \mathrm{mg}$ (57\%); $R_{f}=0.12$ (EtOAc/hexane 50:50); m.p. = 108-110 C; IR $\left(\nu\left(\mathrm{cm}^{-1}\right)\right): 3300-3000\left(\mathrm{C}_{\mathrm{ar}} \mathrm{O}-\mathrm{H}\right), 1693(\mathrm{C}=\mathrm{O})$, 1598-1450 (C=C), 1280, 1153 (C-O); ${ }^{1} \mathrm{H}$ NMR $(400 \mathrm{MHz}$, DMSO $\left.-\mathrm{d}_{6}, 25^{\circ} \mathrm{C}\right), \delta(\mathrm{ppm}): 9.36\left(\mathrm{~s}, 1 \mathrm{H}, \mathrm{C}_{\mathrm{ar}} \mathrm{OH}\right), 9.19(\mathrm{~s}$, $\left.1 \mathrm{H}, \mathrm{C}_{\mathrm{ar}} \mathrm{OH}\right), 8.10(\mathrm{~s}, 1 \mathrm{H},=\mathrm{CHN}), 7.51-7.47(\mathrm{~d}, 1 \mathrm{H}, \mathrm{J}=$ $\left.15.9 \mathrm{~Hz},=\mathrm{CHC}_{\mathrm{ar}}\right), 7.29-7.19\left(\mathrm{~m}, 5 \mathrm{H}, \mathrm{H}_{\mathrm{ar}}\right), 7.06-7.00(\mathrm{~m}, 2 \mathrm{H}$, $\left.\mathrm{H}_{\mathrm{ar}}\right), 6.78-6.76\left(\mathrm{~m}, 1 \mathrm{H}, \mathrm{H}_{\mathrm{ar}}\right), 6.29-6.25(\mathrm{~d}, 1 \mathrm{H}, J=15.9 \mathrm{~Hz}$, $=\mathrm{CHCO}), 5.20\left(\mathrm{~s}, 2 \mathrm{H},-\mathrm{OCH}_{2} \mathrm{C}\right), 4.64-4.60(\mathrm{t}, 2 \mathrm{H}, J=7.2 \mathrm{~Hz}$, $\left.-\mathrm{NCH}_{2} \mathrm{C}\right), 3.18-3.15\left(\mathrm{t}, 2 \mathrm{H}, \mathrm{J}=7.2 \mathrm{~Hz},-\mathrm{CH}_{2} \mathrm{C}_{\mathrm{ar}}\right) ;{ }^{13} \mathrm{C} \mathrm{NMR}$

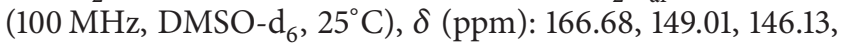
$146.04,142.38,138.04,129.14,128.87,127.04,125.88,125.20$, $121.97,116.19,115.34,113.93,57.45,50.90,36.13 ;$ HRMS $m / s$ calc. for $\mathrm{C}_{19} \mathrm{H}_{17} \mathrm{~N}_{3} \mathrm{O}_{4}+\left(\mathrm{H}^{+}\right)$: 366.1448 ; found: 366.1454 .

[1-(3-Phenylpropyl)-1H-1,2,3-triazol-4-yl]methyl (E)-3-(3,4 dihydroxyphenyl) acrylate $8 \boldsymbol{c}$. 1-Bromo-3-phenylpropane (7c) $(72 \mu \mathrm{l}, 0.47 \mathrm{mmol}), \mathrm{NaN}_{3} \quad(40.66 \mathrm{mg}, 0.63 \mathrm{mmol})$, $6(100.18 \mathrm{mg}, \quad 0.46 \mathrm{mmol}), \quad \mathrm{CuSO}_{4} \cdot 5 \mathrm{H}_{2} \mathrm{O} \quad(60.94 \mathrm{mg}$, $0.24 \mathrm{mmol})$, and sodium ascorbate $(10.66 \mathrm{mg}, 0.054 \mathrm{mmol})$. A beige solid is obtained after flash chromatography (EtOAc/hexane 50:50). Yield: $92.9 \mathrm{mg}$ (53\%); $R_{f}=0.12$ (EtOAc/hexane 50:50); m.p. $=122-125^{\circ} \mathrm{C}$; IR $\left(\nu\left(\mathrm{cm}^{-1}\right)\right)$ : 3486, $3309\left(\mathrm{C}_{\mathrm{ar}} \mathrm{O}-\mathrm{H}\right), 1685(\mathrm{C}=\mathrm{O}), 1603-1450(\mathrm{C}=\mathrm{C}), 1277$, 1169 (C-O); ${ }^{1} \mathrm{H}$ NMR (400 MHz, DMSO-d $\left.{ }_{6}, 25^{\circ} \mathrm{C}\right), \delta(\mathrm{ppm})$ : $9.63\left(\mathrm{~s}, 1 \mathrm{H}, \mathrm{C}_{\mathrm{ar}} \mathrm{OH}\right), 9.17\left(\mathrm{~s}, 1 \mathrm{H}, \mathrm{C}_{\mathrm{ar}} \mathrm{OH}\right), 8.22(\mathrm{~s}, 1 \mathrm{H},=\mathrm{CHN})$, $7.53-7.49\left(\mathrm{~d}, 1 \mathrm{H}, J=15.9 \mathrm{~Hz},=\mathrm{CHC}_{\mathrm{ar}}\right), 7.31-7.18\left(\mathrm{~m}, 5 \mathrm{H}, \mathrm{H}_{\mathrm{ar}}\right)$, 7.06-7.00 (m, 2H, $\left.\mathrm{H}_{\mathrm{ar}}\right), 6.77-6.75\left(\mathrm{~m}, 1 \mathrm{H}, \mathrm{H}_{\mathrm{ar}}\right), 6.31-6.27(\mathrm{~d}$, $1 \mathrm{H} J=15.9 \mathrm{~Hz},=\mathrm{CHCO}), 5.24\left(\mathrm{~s}, 2 \mathrm{H}, \mathrm{OCH}_{2} \mathrm{C}=\right)$ ), 4.40-4.36 $\left(\mathrm{t}, 2 \mathrm{H}, J=7.1 \mathrm{~Hz}, \mathrm{NCH}_{2}-\right), 2.59-2.55(\mathrm{t}, 2 \mathrm{H} J=7.4 \mathrm{~Hz}$, $-\mathrm{CH}_{2} \mathrm{C}_{\mathrm{ar}}$ ), 2.18-2.12 (quint, $2 \mathrm{H}, J=7.4 \mathrm{~Hz},-\mathrm{CH}_{2}-$ ); ${ }^{13} \mathrm{C} \mathrm{NMR}$ $\left(100 \mathrm{MHz}, \mathrm{DMSO}_{-} \mathrm{d}_{6}, 25^{\circ} \mathrm{C}\right), \delta$ (ppm): 166.74, 149.01, 146.15, $146.04,142.58,141.18,128.86,128.78,126.47,125.88,125.12$, $122.00,116.18,115.32,113.92,57.51,49.40,32.32$, 31.75; HRMS $\mathrm{m} / \mathrm{s}$ calc. for $\mathrm{C}_{19} \mathrm{H}_{17} \mathrm{~N}_{3} \mathrm{O}_{4}+\left(\mathrm{H}^{+}\right): 380.1605$; found: 380.1622 .

\{1-[2-(p-Tolyl)ethyl]-1H-1,2,3-triazol-4-yl\}methyl (E)-3-(3,4dihydroxyphenyl) acrylate 10a. p-(2-Bromoethyl)toluene (9a) (157.18 $\mu \mathrm{l}, 1.03 \mathrm{mmol}), \mathrm{NaN}_{3}$ (75.92 mg, $\left.1.16 \mathrm{mmol}\right), 6$
(154.02 mg, $0.71 \mathrm{mmol}), \mathrm{CuSO}_{4} \cdot 5 \mathrm{H}_{2} \mathrm{O}(38.42 \mathrm{mg}, 0.15 \mathrm{mmol})$, and sodium ascorbate $(15.49 \mathrm{mg}, 0.08 \mathrm{mmol})$. A beige solid is obtained after flash chromatography (EtOAc/hexane $50: 50)$. Yield: $173.8 \mathrm{mg}(65 \%) ; R_{f}=0.13$ (EtOAc/hexane $50: 50)$; m.p. $=123-126^{\circ} \mathrm{C}$; IR $\left(\nu\left(\mathrm{cm}^{-1}\right)\right): 3477\left(\mathrm{C}_{\mathrm{ar}} \mathrm{O}-\mathrm{H}\right)$, $1702(\mathrm{C}=\mathrm{O}), 1601-1447(\mathrm{C}=\mathrm{C}), 1281,1160(\mathrm{C}-\mathrm{O}) ;{ }^{1} \mathrm{H}$ NMR (400 MHz, DMSO-d $\left.{ }_{6}, 25^{\circ} \mathrm{C}\right), \delta(\mathrm{ppm}): 9.64\left(\mathrm{~s}, 1 \mathrm{H}, \mathrm{C}_{\mathrm{ar}} \mathrm{OH}\right)$, $9.18\left(\mathrm{~s}, 1 \mathrm{H}, \mathrm{C}_{\mathrm{ar}} \mathrm{OH}\right), 8.08(\mathrm{~s}, 1 \mathrm{H},=\mathrm{CHN}), 7.51-7.47(\mathrm{~d}, 1 \mathrm{H}, J$ $\left.=15.9 \mathrm{~Hz},=\mathrm{CHC}_{\mathrm{ar}}\right), 7.06-7.00\left(\mathrm{~m}, 6 \mathrm{H}, \mathrm{H}_{\mathrm{ar}}\right), 6.78-6.76(\mathrm{~m}$, $\left.1 \mathrm{H}, \mathrm{H}_{\mathrm{ar}}\right), 6.29-6.25(\mathrm{~d}, 1 \mathrm{H}, J=15.9 \mathrm{~Hz},=\mathrm{CHCO}), 5.20(\mathrm{~s}, 2 \mathrm{H}$, $\left.-\mathrm{OCH}_{2} \mathrm{C}\right), 4.60-4.56\left(\mathrm{t}, 2 \mathrm{H}, \mathrm{J}=7.2 \mathrm{~Hz},-\mathrm{NCH}_{2} \mathrm{C}\right), 3.13-3.09$ $\left(\mathrm{t}, 2 \mathrm{H}, \mathrm{J}=7.2 \mathrm{~Hz},-\mathrm{CH}_{2} \mathrm{C}_{\mathrm{ar}}\right), 2.23\left(\mathrm{~s}, 3 \mathrm{H}, \mathrm{C}_{\mathrm{ar}} \mathrm{CH}_{3}\right) ;{ }^{13} \mathrm{C} \mathrm{NMR}$ $\left(100 \mathrm{MHz}, \mathrm{DMSO}-\mathrm{d}_{6}, 25^{\circ} \mathrm{C}\right), \delta$ (ppm): 166.68, 149.01, 146.12, $146.04,142.37,136.02,134.89,129.43,129.00,125.88,125.20$, $122.00,116.19,115.29,113.92,57.44,51.01,35.71,21.07$; HRMS $\mathrm{m} / \mathrm{s}$ calc. for $\mathrm{C}_{21} \mathrm{H}_{22} \mathrm{~N}_{3} \mathrm{O}_{4}+\left(\mathrm{H}^{+}\right)$: 380.1605 ; found: 380.1623 .

\{1-[2-(p-Methoxyphenyl)ethyl]-1H-1,2,3-triazol-4-yl $\}$ methyl (E)-3-(3,4-dihydroxyphenyl) acrylate 10b. p-(2-Bromoethyl)methoxybenzene (9b) (108 $\mu \mathrm{l}, \quad 0.69 \mathrm{mmol}), \quad \mathrm{NaN}_{3}$ (49.77 mg, $0.77 \mathrm{mmol}$ ), 6 (150.38 mg, $0.69 \mathrm{mmol}$ ), $\mathrm{CuSO}_{4}$. $5 \mathrm{H}_{2} \mathrm{O} \quad(36.85 \mathrm{mg}, \quad 0.15 \mathrm{mmol})$, and sodium ascorbate (16.17 mg, $0.082 \mathrm{mmol})$. A white solid is obtained after flash chromatography (EtOAc/hexane 60:40). Yield: $176.2 \mathrm{mg}$ $(65 \%) ; R_{f}=0.09$ (EtOAc/hexane $\left.50: 50\right) ;$ m.p. $=153-154^{\circ} \mathrm{C}$; IR $\left(\nu\left(\mathrm{cm}^{-1}\right)\right): 3471\left(\mathrm{C}_{\mathrm{ar}} \mathrm{O}-\mathrm{H}\right), 1700(\mathrm{C}=\mathrm{O}), 1620-1440$ $(\mathrm{C}=\mathrm{C}), 1280,1250,1160$ (C-O); ${ }^{1} \mathrm{H}$ NMR (400 MHz, DMSO$\left.\mathrm{d}_{6}, 25^{\circ} \mathrm{C}\right), \delta(\mathrm{ppm}): 9.62\left(\mathrm{~s}, 1 \mathrm{H}, \mathrm{C}_{\mathrm{ar}} \mathrm{OH}\right), 9.15\left(\mathrm{~s}, 1 \mathrm{H}, \mathrm{C}_{\mathrm{ar}} \mathrm{OH}\right)$, $8.09(\mathrm{~s}, 1 \mathrm{H},=\mathrm{CHN}), 7.52-7.48\left(\mathrm{~d}, 1 \mathrm{H}, J=15.9 \mathrm{~Hz},=\mathrm{CHC}_{\mathrm{ar}}\right)$, 7.11-7.00 (m, 4H, $\left.\mathrm{H}_{\mathrm{ar}}\right), 6.84-6.76\left(\mathrm{~m}, 3 \mathrm{H}, \mathrm{H}_{\mathrm{ar}}\right), 6.30-6.26(\mathrm{~d}$, $1 \mathrm{H}, J=15.9 \mathrm{~Hz},=\mathrm{CHCO}), 5.20\left(\mathrm{~s}, 2 \mathrm{H}, \mathrm{OCH}_{2} \mathrm{C}=\right)$, 4.59-4.55 $\left(\mathrm{t}, 2 \mathrm{H}, J=7.2 \mathrm{~Hz}, \mathrm{NCH}_{2} \mathrm{C}\right), 3.69\left(\mathrm{~s}, 3 \mathrm{H}, \mathrm{OCH}_{3}\right), 3.11-3.07$ $\left(\mathrm{t}, 2 \mathrm{H}, J=7.2 \mathrm{~Hz},-\mathrm{CH}_{2} \mathrm{C}_{\mathrm{ar}}\right) ;{ }^{13} \mathrm{C}$ NMR $(100 \mathrm{MHz}$, DMSO$\left.\mathrm{d}_{6}, 25^{\circ} \mathrm{C}\right), \delta$ (ppm): 166.68, 158.43, 149.01, 146.13, 146.04, $142.36,130.16,129.83,125.88,125.18,121.98,116.18,115.34$, $114.27,113.92,57.46,55.41,51.18,35.29$; HRMS $\mathrm{m} / \mathrm{s}$ calc. for $\mathrm{C}_{19} \mathrm{H}_{17} \mathrm{~N}_{3} \mathrm{O}_{4}+\left(\mathrm{H}^{+}\right)$: 396.1554; found: 396.1530 .

$\{1-[2-(p-F l u o r o p h e n y l) e t h y l]-1 H-1,2,3-$ triazol-4-yl $\}$ methyl (E)3-(3,4-dihydroxyphenyl) acrylate 10c. p-(2-Bromoethyl)fluorobenzene (9c) (144.41 $\mu \mathrm{l}, 1.03 \mathrm{mmol}), \mathrm{NaN}_{3}$ (70.05 mg, $1.08 \mathrm{mmol}), \quad 6 \quad(151.17 \mathrm{mg}, \quad 0.69 \mathrm{mmol}), \quad \mathrm{CuSO}_{4} \cdot 5 \mathrm{H}_{2} \mathrm{O}$ (45.65 mg, $0.18 \mathrm{mmol}$ ), and sodium ascorbate $(16.07 \mathrm{mg}$, $0.08 \mathrm{mmol})$. A pale yellow solid is obtained after flash chromatography (EtOAc/hexane $50: 50)$. Yield: $168.0 \mathrm{mg}$ $(63 \%) ; R_{f}=0.11($ EtOAc/hexane $50: 50) ;$ m.p. $=48-53^{\circ} \mathrm{C}$; IR $\left(\nu\left(\mathrm{cm}^{-1}\right)\right): 3300-3000\left(\mathrm{C}_{\mathrm{ar}} \mathrm{O}-\mathrm{H}\right), 1702(\mathrm{C}=\mathrm{O}), 1600-1440$ (C=C), 1220, 1151 (C-O), $1210(\mathrm{C}-\mathrm{F}) ;{ }^{1} \mathrm{H}$ NMR $(400 \mathrm{MHz}$, DMSO- $\left.\mathrm{d}_{6}, 25^{\circ} \mathrm{C}\right), \delta(\mathrm{ppm}): 9.26\left(\mathrm{~m}, 3 \mathrm{H}, \mathrm{C}_{\mathrm{ar}} \mathrm{OH}\right), 8.09(\mathrm{~s}, 1 \mathrm{H}$, $=\mathrm{CHN}), 7.52-7.48\left(\mathrm{~d}, 1 \mathrm{H}, J=15.9 \mathrm{~Hz},=\mathrm{CHC}_{\mathrm{ar}}\right), 7.06-6.97$ $\left(\mathrm{m}, 4 \mathrm{H}, \mathrm{H}_{\mathrm{ar}}\right), 6.78-6.76\left(\mathrm{~m}, 1 \mathrm{H}, \mathrm{H}_{\mathrm{ar}}\right), 6.67-6.65(\mathrm{~m}, 2 \mathrm{H}$, $\left.\mathrm{H}_{\mathrm{ar}}\right), 6.30-6.26(\mathrm{~d}, 1 \mathrm{H}, J=15.9 \mathrm{~Hz},=\mathrm{CHCO}), 5.20(\mathrm{~s}, 2 \mathrm{H}$, $-\mathrm{OCH}_{2} \mathrm{C}$ ), 4.55-4.52 (t, 2H, J = 7.3 Hz, NCH${ }_{2} \mathrm{C}$ ), 3.05-3.02 $\left(\mathrm{t}, 2 \mathrm{H}, J=7.3 \mathrm{~Hz},-\mathrm{CH}_{2} \mathrm{C}_{\mathrm{ar}}\right) ;{ }^{13} \mathrm{C}$ NMR $\left(100 \mathrm{MHz}, \mathrm{DMSO}-\mathrm{d}_{6}\right.$, $\left.25^{\circ} \mathrm{C}\right), \delta$ (ppm): 166.71, 156.44, 149.00, 146.13, 146.03, 142.33, 130.07, 128.01, 125.88, 125.14, 122.01, 116.19115.66, 115.30, 113.92, 57.47, 51.30, 35.41; HRMS $m / s$ calc. for $\mathrm{C}_{20} \mathrm{H}_{19} \mathrm{~N}_{3} \mathrm{O}_{4}+\left(\mathrm{H}^{+}\right)$: 384.1354; found: 384.1375 . 
\{1-[2-(p-Tolyl)ethyl]-1H-1,2,3-triazol-4-yl\}methyl (E)-3-(3,4dihydroxyphenyl) acrylate 10d. p-(2-Bromoethyl)phenol (9d) $(212.59 \mathrm{mg}, 1.06 \mathrm{mmol}), \mathrm{NaN}_{3}(78.20 \mathrm{mg}, 1.20 \mathrm{mmol})$, $6 \quad(156.05 \mathrm{mg}, \quad 0.72 \mathrm{mmol}), \quad \mathrm{CuSO}_{4} \cdot 5 \mathrm{H}_{2} \mathrm{O} \quad(42.50 \mathrm{mg}$, $0.17 \mathrm{mmol})$, and sodium ascorbate $(20.41 \mathrm{mg}, 0.11 \mathrm{mmol})$. A white solid is obtained after flash chromatography (EtOAc/ hexane $70: 30)$. Yield $=129.4 \mathrm{mg}(47 \%) ; R_{f}=0.19($ EtOAcl hexane $70: 30) ; \mathrm{m} . \mathrm{p} .=70-75^{\circ} \mathrm{C}$; IR $\left(\nu\left(\mathrm{cm}^{-1}\right)\right): 3400-3000$ $\left(\mathrm{C}_{\mathrm{ar}} \mathrm{O}-\mathrm{H}\right), 2922\left(\mathrm{C}_{\mathrm{sp} 3}-\mathrm{H}\right), 1687(\mathrm{C}=\mathrm{O}), 1598-1440(\mathrm{C}=\mathrm{C})$, 1270, 1230, 1156 (C-O); ${ }^{1} \mathrm{H}$ NMR $\left(400 \mathrm{MHz}\right.$, DMSO-d ${ }_{6}$, $\left.25^{\circ} \mathrm{C}\right), \delta(\mathrm{ppm}): 9.26\left(\mathrm{~m}, 3 \mathrm{H}, \mathrm{C}_{\mathrm{ar}} \mathrm{OH}\right), 8.09(\mathrm{~s}, 1 \mathrm{H},=\mathrm{CHN})$, $7.52-7.48\left(\mathrm{~d}, 1 \mathrm{H}, J=15.9 \mathrm{~Hz},=\mathrm{CHC}_{\mathrm{ar}}\right), 7.06-6.97\left(\mathrm{~m}, 4 \mathrm{H}, \mathrm{H}_{\mathrm{ar}}\right)$, 6.78-6.76 (m, 1H, $\left.\mathrm{H}_{\mathrm{ar}}\right), 6.67-6.65\left(\mathrm{~m}, 2 \mathrm{H}, \mathrm{H}_{\mathrm{ar}}\right), 6.30-6.26(\mathrm{~d}$, $1 \mathrm{H}, J=15.9 \mathrm{~Hz},=\mathrm{CHCO}), 5.20\left(\mathrm{~s}, 2 \mathrm{H},-\mathrm{OCH}_{2} \mathrm{C}\right), 4.55-4.52$ $\left(\mathrm{t}, 2 \mathrm{H}, J=7.3 \mathrm{~Hz}, \mathrm{NCH}_{2} \mathrm{C}\right), 3.05-3.02(\mathrm{t}, 2 \mathrm{H}, J=7.3 \mathrm{~Hz}$, $\left.-\mathrm{CH}_{2} \mathrm{C}_{\mathrm{ar}}\right) ;{ }^{13} \mathrm{C}$ NMR $\left(100 \mathrm{MHz}, \mathrm{DMSO}-\mathrm{d}_{6}, 25^{\circ} \mathrm{C}\right), \delta(\mathrm{ppm})$ : $166.71,156.44,149.00,146.13,146.03,142.33,130.07,128.01$, $125.88,125.14,122.01,116.19,115.66,115.30,113.92,57.47,51.30$, 35.41; HRMS $\mathrm{m} / \mathrm{s}$ calc. for $\mathrm{C}_{20} \mathrm{H}_{20} \mathrm{~N}_{3} \mathrm{O}_{5}+\left(\mathrm{H}^{+}\right)$: 382.1397; found: 382.1392 .

(1-\{2-[p-(Trifluoromethyl)phenyl]ethyl $\}-1 H-1,2,3-$ triazol-4yl)methyl (E)-3-(3,4-dihydroxyphenyl)acrylate 10e. p-(2-Bromoethyl)(trifluoromethyl)benzene $(9 \mathrm{e})(120 \mu \mathrm{l}, 0.71 \mathrm{mmol})$, $\mathrm{NaN}_{3}$ (49.71 mg, $\left.0.77 \mathrm{mmol}\right), 6(153.03 \mathrm{mg}, 0.70 \mathrm{mmol})$, $\mathrm{CuSO}_{4} \cdot 5 \mathrm{H}_{2} \mathrm{O}(40.57 \mathrm{mg}, 0.16 \mathrm{mmol})$, and sodium ascorbate $(15.18 \mathrm{mg}, 0.077 \mathrm{mmol})$. A white solid is obtained after flash chromatography (EtOAc/hexane 55:45). Yield: $205.6 \mathrm{mg}$ $(68 \%) ; R_{f}=0.10($ EtOAc/hexane $50: 50) ;$ m.p. $=150-151^{\circ} \mathrm{C}$; IR $\left(\nu\left(\mathrm{cm}^{-1}\right)\right): 3400-3000\left(\mathrm{C}_{\mathrm{ar}} \mathrm{O}-\mathrm{H}\right), 1695(\mathrm{C}=\mathrm{O}), 1600-1440$ $(\mathrm{C}=\mathrm{C}), 1270,1156(\mathrm{C}-\mathrm{O}), 1220(\mathrm{C}-\mathrm{F}) ;{ }^{1} \mathrm{H}$ NMR $(400 \mathrm{MHz}$, DMSO- $\left.\mathrm{d}_{6}, 25^{\circ} \mathrm{C}\right), \delta(\mathrm{ppm}): 9.67\left(\mathrm{~s}, 1 \mathrm{H}, \mathrm{C}_{\mathrm{ar}} \mathrm{OH}\right), 9.19(\mathrm{~s}, 1 \mathrm{H}$, $\left.\mathrm{C}_{\mathrm{ar}} \mathrm{OH}\right), 8.15(\mathrm{~s}, 1 \mathrm{H},=\mathrm{CHN}), 7.64-7.63\left(\mathrm{~m}, 2 \mathrm{H}, \mathrm{H}_{\mathrm{ar}}\right), 7.52-7.48$ $\left(\mathrm{d}, 1 \mathrm{H}, J=15.9 \mathrm{~Hz},=\mathrm{CHC}_{\mathrm{ar}}\right), 7.43-7.41\left(\mathrm{~m}, 2 \mathrm{H}, \mathrm{H}_{\mathrm{ar}}\right), 7.06-7.00$ $\left(\mathrm{m}, 2 \mathrm{H}, \mathrm{H}_{\mathrm{ar}}\right), 6.78-6.76\left(\mathrm{~m}, 1 \mathrm{H}, \mathrm{H}_{\mathrm{ar}}\right), 6.29-6.26(\mathrm{~d}, 1 \mathrm{H}, J=$ $15.9 \mathrm{~Hz},=\mathrm{CHCO}), 5.20\left(\mathrm{~s}, 2 \mathrm{H},-\mathrm{OCH}_{2} \mathrm{C}\right), 4.69-4.65(\mathrm{t}, 2 \mathrm{H}, \mathrm{J}$ $=7.2 \mathrm{~Hz}, \mathrm{NCH}_{2} \mathrm{C}$ ), $3.29-3.26\left(\mathrm{t}, 2 \mathrm{H}, J=7.2 \mathrm{~Hz},-\mathrm{CCH}_{2} \mathrm{C}_{\mathrm{ar}}\right.$ ); ${ }^{13} \mathrm{C}$ NMR $\left(100 \mathrm{MHz}\right.$, DMSO-d $\left.\mathrm{d}_{6}, 25^{\circ} \mathrm{C}\right), \delta$ (ppm): 166.68 , $149.01,146.16,146.03,143.05,142.49,130.04,125.86,125.67$, $125.64,125.28,121.97,116.16,115.32,113.86,57.43,55.37,50.40$, 35.77; HRMS $\mathrm{m} / \mathrm{s}$ calc. for $\mathrm{C}_{19} \mathrm{H}_{17} \mathrm{~N}_{3} \mathrm{O}_{4}+\left(\mathrm{H}^{+}\right)$: 434.1322; found: 434.1314 .

\{1-[2-(p-Nitrophenyl)ethyl]-1H-1,2,3-triazol-4-yl\} methyl(E)3-(3,4-dihydroxy-phenyl) acrylate 10f. p-(2-Bromoethyl)nitrobenzene (9f) $\quad(161.25 \mathrm{mg}, \quad 0.70 \mathrm{mmol}), \quad \mathrm{NaN}_{3}$ (46.81 mg, $0.72 \mathrm{mmol}), 6(149.83 \mathrm{mg}, 0.69 \mathrm{mmol}), \mathrm{CuSO}_{4}$. $5 \mathrm{H}_{2} \mathrm{O} \quad(40.68 \mathrm{mg}, \quad 0.16 \mathrm{mmol})$, and sodium ascorbate (23.51 mg, $0.12 \mathrm{mmol}$ ). A yellow solid is obtained after flash chromatography (EtOAc/hexane $70: 30)$. Yield $=149.7 \mathrm{mg}$ (53\%); $R_{f}=0.19(\mathrm{EtOAc} /$ hexane $7: 3) ; \mathrm{m} . \mathrm{p} .=159-161^{\circ} \mathrm{C}$; IR $\left(\nu\left(\mathrm{cm}^{-1}\right)\right): 3445\left(\mathrm{C}_{\mathrm{ar}} \mathrm{O}-\mathrm{H}\right), 2920\left(\mathrm{C}_{\mathrm{sp} 3}-\mathrm{H}\right), 1719(\mathrm{C}=\mathrm{O})$, 1603-1440 (C=C), 1520, $1340\left(\mathrm{NO}_{2}\right), 1255,1151(\mathrm{C}-\mathrm{O}) ;{ }^{1} \mathrm{H}$ NMR $\left(400 \mathrm{MHz}, \mathrm{DMSO}_{6}, \mathrm{~d}_{6} 5^{\circ} \mathrm{C}\right), \delta(\mathrm{ppm}): 9.64(\mathrm{~s}, 1 \mathrm{H}$, $\left.\mathrm{C}_{\mathrm{ar}} \mathrm{OH}\right), 9.17\left(\mathrm{~s}, 1 \mathrm{H}, \mathrm{C}_{\mathrm{ar}} \mathrm{OH}\right), 8.14(\mathrm{~s}, 1 \mathrm{H},=\mathrm{CHN}), 8.12-8.11$ $\left(\mathrm{m}, 2 \mathrm{H}, \mathrm{H}_{\mathrm{ar}}\right), 7.51-7.47\left(\mathrm{~d}, 1 \mathrm{H}, J=15.9 \mathrm{~Hz},=\mathrm{CHC}_{\mathrm{ar}}\right), 7.49$ $\left(\mathrm{m}, 2 \mathrm{H}, \mathrm{H}_{\mathrm{ar}}\right), 7.05-6.99\left(\mathrm{~m}, 2 \mathrm{H}, \mathrm{H}_{\mathrm{ar}}\right), 6.77-6.75(\mathrm{~m}, 1 \mathrm{H}$, $\left.\mathrm{H}_{\mathrm{ar}}\right), 6.28-6.24(\mathrm{~d}, 1 \mathrm{H}, J=15.9 \mathrm{~Hz},=\mathrm{CHCO}), 5.19(\mathrm{~s}, 2 \mathrm{H}$,
$\left.-\mathrm{OCH}_{2} \mathrm{C}\right), 4.71-4.68\left(\mathrm{t}, 2 \mathrm{H}, J=7.2 \mathrm{~Hz}, \mathrm{NCH}_{2} \mathrm{C}\right), 3.33-3.31(\mathrm{t}$, $\left.2 \mathrm{H}, J=7.2 \mathrm{~Hz},-\mathrm{CCH}_{2} \mathrm{C}_{\mathrm{ar}}\right) ;{ }^{13} \mathrm{C}$ NMR $\left(100 \mathrm{MHz}\right.$, DMSO-d $\mathrm{d}_{6}$, $\left.25^{\circ} \mathrm{C}\right), \delta$ (ppm): 166.67, 149.02, 146.84, 146.39, 146.16, 146.04, $142.52,130.56,125.87,125.30,123.90,121.97,116.18,115.35$, 113.86, 57.43, 50.17, 35.73; HRMS $m / s$ calc. for $\mathrm{C}_{19} \mathrm{H}_{17} \mathrm{~N}_{3} \mathrm{O}_{4}+$ $\left(\mathrm{H}^{+}\right)$: 411.1299; found: 411.1276.

(1-Methyl-1H-1,2,3-triazol-4-yl)methyl (E)-3-(3,4-dihydroxyphenyl)acrylate 12a. A solution of iodomethane (11a) $(64.19 \mu \mathrm{l}, 1.03 \mathrm{mmol}), \mathrm{NaN}_{3} \quad(72.03 \mathrm{mg}, 1.11 \mathrm{mmol}), \quad 6$ $(154.45 \mathrm{mg}, 0.71 \mathrm{mmol})$, and copper iodine $(27.87 \mathrm{mg}$, $0.15 \mathrm{mmol})$ in $5 \mathrm{ml}$ of a mixture of water and acetone $(1: 1)$ was placed in an ultrasound bath and was left to react under ultrasound at room temperature overnight. The solution was then extracted 3 times with EtOAc. The combined organic phases are washed twice with a solution of $\mathrm{NH}_{4} \mathrm{Cl} 5 \mathrm{M}$ and then twice with brine. The combined organic phase is dried with $\mathrm{MgSO}_{4}$ and concentrated under vacuum to afford the crude product. Compound 12a was obtained as brown solid after flash chromatography (EtOAc/Hexane 70:30). Yield $=45.9 \mathrm{mg}(24 \%) ; R_{f}=0.14($ EtOAc/hexane $70: 30)$; m.p. $=49-55^{\circ} \mathrm{C}$; IR $\left(\nu\left(\mathrm{cm}^{-1}\right)\right): 3400-3000\left(\mathrm{C}_{\mathrm{ar}} \mathrm{O}-\mathrm{H}\right), 2922$ $\left(\mathrm{C}_{\mathrm{sp} 3}-\mathrm{H}\right), 1696(\mathrm{C}=\mathrm{O}), 1598-1440(\mathrm{C}=\mathrm{C}), 1251,1147(\mathrm{C}-\mathrm{O})$; ${ }^{1} \mathrm{H}$ NMR (400 MHz, $\mathrm{CD}_{3} \mathrm{OD}, 25^{\circ} \mathrm{C}$ ), $\delta$ (ppm): 8.00 (s, $1 \mathrm{H}$, $=\mathrm{CHN}), 7.61-7.57\left(\mathrm{~d}, 1 \mathrm{H}, J=15.9 \mathrm{~Hz},=\mathrm{CHC}_{\mathrm{ar}}\right), 7.04-6.94$ $\left(\mathrm{m}, 2 \mathrm{H}, \mathrm{H}_{\mathrm{ar}}\right), 6.80-6.78\left(\mathrm{~m}, 1 \mathrm{H}, \mathrm{H}_{\mathrm{ar}}\right), 6.29-6.25(\mathrm{~d}, 1 \mathrm{H}, J=$ $15.9 \mathrm{~Hz},=\mathrm{CHCO}), 5.29\left(\mathrm{~s}, 2 \mathrm{H},-\mathrm{OCH}_{2} \mathrm{C}\right), 4.13\left(\mathrm{~s}, 3 \mathrm{H}, \mathrm{NCH}_{3}\right)$; ${ }^{13} \mathrm{C}$ NMR $\left(100 \mathrm{MHz}, \mathrm{CD}_{3} \mathrm{OD}, 25^{\circ} \mathrm{C}\right), \delta$ (ppm): $167.24,148.33$, $146.09,145.43,142.98,126.20,125.32,121.65,115.09,113.73$, 113.12, 56.66, 35.62; HRMS m/s calc. for $\mathrm{C}_{13} \mathrm{H}_{13} \mathrm{~N}_{3} \mathrm{O}_{4}+\left(\mathrm{H}^{+}\right)$: 276.0979; found: 276.0997 .

(1-Ethyl-1H-1,2,3-triazol-4-yl)methyl (E)-3-(3,4-dihydroxyphenyl)acrylate 12b. Bromoethane (11b) $(80 \mu \mathrm{l}, 1.08 \mathrm{mmol})$, $\mathrm{NaN}_{3}(61.01 \mathrm{mg}, 0.88 \mathrm{mmol}), 6(148.72 \mathrm{mg}, 0.68 \mathrm{mmol})$, $\mathrm{CuSO}_{4} \cdot 5 \mathrm{H}_{2} \mathrm{O}(41.62 \mathrm{mg}, 0.17 \mathrm{mmol})$, and sodium ascorbate $(20.94 \mathrm{mg}, 0.11 \mathrm{mmol})$. A beige solid is obtained after flash chromatography (EtOAc/hexane $70: 30$ ). Yield: $127.5 \mathrm{mg}$ $(59 \%) ; R_{f}=0.19($ EtOAc/hexane $70: 30) ; \mathrm{m} . \mathrm{p} .=188-191^{\circ} \mathrm{C}$; IR $\left(\nu\left(\mathrm{cm}^{-1}\right)\right): 3400-3000\left(\mathrm{C}_{\mathrm{ar}} \mathrm{O}-\mathrm{H}\right), 2924\left(\mathrm{C}_{\mathrm{sp} 3}-\mathrm{H}\right), 1687(\mathrm{C}=\mathrm{O})$, 1596-1440 (C=C), 1257, 1147 (C-O); ${ }^{1} \mathrm{H}$ NMR $(400 \mathrm{MHz}$, DMSO- $\left._{6}, 25^{\circ} \mathrm{C}\right), \delta(\mathrm{ppm}): 9.62\left(\mathrm{~s}, 1 \mathrm{H}, \mathrm{C}_{\mathrm{ar}} \mathrm{OH}\right), 9.19(\mathrm{~s}, 1 \mathrm{H}$, $\left.\mathrm{C}_{\mathrm{ar}} \mathrm{OH}\right), 8.19(\mathrm{~s}, 1 \mathrm{H},=\mathrm{CHN}), 7.52-7.48(\mathrm{~d}, 1 \mathrm{H}, J=15.9 \mathrm{~Hz}$, $\left.=\mathrm{CHC}_{\mathrm{ar}}\right), 7.05-7.00\left(\mathrm{~m}, 2 \mathrm{H}, \mathrm{H}_{\mathrm{ar}}\right), 6.77-6.75\left(\mathrm{~m}, 1 \mathrm{H}, \mathrm{H}_{\mathrm{ar}}\right)$, $6.30-6.26(\mathrm{~d}, 1 \mathrm{H}, J=15.9 \mathrm{~Hz},=\mathrm{CHCO}), 5.22\left(\mathrm{~s}, 2 \mathrm{H},-\mathrm{OCH}_{2} \mathrm{C}\right)$, $4.42-4.36\left(\mathrm{q}, 2 \mathrm{H}, J=7.3 \mathrm{~Hz},-\mathrm{CH}_{2} \mathrm{C}\right), 1.45-1.41(\mathrm{t}, 3 \mathrm{H}, J$ $\left.=7.3 \mathrm{~Hz},-\mathrm{CH}_{3}\right) ;{ }^{13} \mathrm{C}$ NMR $\left(100 \mathrm{MHz}, \mathrm{DMSO}-\mathrm{d}_{6}, 25^{\circ} \mathrm{C}\right), \delta$ (ppm): 166.74, 149.00, 146.15, 146.03, 142.51, 125.87, 124.63, $122.00,116.18,115.30,113.91,57.50,45.06,15.82 ;$ HRMS $\mathrm{m} / \mathrm{s}$ calc. for $\mathrm{C}_{19} \mathrm{H}_{17} \mathrm{~N}_{3} \mathrm{O}_{4}+\left(\mathrm{H}^{+}\right)$: 320.0877 ; found: 320.0874 .

(1-Propyl-1H-1,2,3-triazol-4-yl)methyl (E)-3-(3,4-dihydroxyphenyl)acrylate 12c. 1-Bromopropane (11c) (88.43 $\mu \mathrm{l}$, $1.03 \mathrm{mmol}), \mathrm{NaN}_{3}(67.37 \mathrm{mg}, 1.04 \mathrm{mmol}), 6(155.09 \mathrm{mg}$, $0.71 \mathrm{mmol}), \quad \mathrm{CuSO}_{4} \cdot 5 \mathrm{H}_{2} \mathrm{O}(44.51 \mathrm{mg}, \quad 0.18 \mathrm{mmol})$, and sodium ascorbate $(23.50 \mathrm{mg}, 0.12 \mathrm{mmol})$. A darker beige solid is obtained after flash chromatography (EtOAc/hexane $50: 50)$. Yield: $118.7 \mathrm{mg}$ (55\%); $R_{f}=0.11$ (EtOAc/hexane 
$50: 50)$; m.p. $=45-50^{\circ} \mathrm{C}$; IR $\left(\nu\left(\mathrm{cm}^{-1}\right)\right): 3334\left(\mathrm{C}_{\mathrm{ar}} \mathrm{O}-\mathrm{H}\right), 2926$ $\left(\mathrm{C}_{\mathrm{sp} 3}-\mathrm{H}\right), 1687(\mathrm{C}=\mathrm{O}), 1605-1440(\mathrm{C}=\mathrm{C}), 1274,1150(\mathrm{C}-\mathrm{O})$; ${ }^{1} \mathrm{H}$ NMR $\left(400 \mathrm{MHz}, \mathrm{DMSO}-\mathrm{d}_{6}, 25^{\circ} \mathrm{C}\right), \delta(\mathrm{ppm}): 9.62(\mathrm{~s}, 1 \mathrm{H}$, $\left.\mathrm{C}_{\mathrm{ar}} \mathrm{OH}\right), 9.14\left(\mathrm{~s}, 1 \mathrm{H}, \mathrm{C}_{\mathrm{ar}} \mathrm{OH}\right), 8.18(\mathrm{~s}, 1 \mathrm{H},=\mathrm{CHN}), 7.53-7.49(\mathrm{~d}$, $\left.1 \mathrm{H}, J=15.9 \mathrm{~Hz},=\mathrm{CHC}_{\mathrm{ar}}\right), 7.05-7.00\left(\mathrm{~m}, 2 \mathrm{H}, \mathrm{H}_{\mathrm{ar}}\right), 6.77-6.75$ $\left(\mathrm{m}, 1 \mathrm{H}, \mathrm{H}_{\mathrm{ar}}\right), 6.30-6.26(\mathrm{~d}, 1 \mathrm{H}, J=15.9 \mathrm{~Hz},=\mathrm{CHCO}), 5.23$ (s, $\left.2 \mathrm{H},-\mathrm{OCH}_{2} \mathrm{C}\right), 4.34-4.31\left(\mathrm{t}, 2 \mathrm{H}, J=7.0 \mathrm{~Hz}, \mathrm{NCH}_{2} \mathrm{C}\right.$ ), 1.88-1.79 (sext, $2 \mathrm{H}, J=7.2 \mathrm{~Hz},-\mathrm{CH}_{2} \mathrm{C}$ ), $0.87-0.83$ (t, $3 \mathrm{H}, J$ $\left.=7.4 \mathrm{~Hz},-\mathrm{CH}_{3}\right) ;{ }^{13} \mathrm{C}$ NMR $\left(100 \mathrm{MHz}\right.$, DMSO- $\left.\mathrm{d}_{6}, 25^{\circ} \mathrm{C}\right), \delta$ (ppm): 166.73, 149.00, 146.15, 146.03, 142.46, 125.88, 125.08, 121.97, 116.18, 115.35, 113.92, 57.51, 51.40, 23.61, 11.27; HRMS $\mathrm{m} / \mathrm{s}$ calc. for $\mathrm{C}_{15} \mathrm{H}_{17} \mathrm{~N}_{3} \mathrm{O}_{4}+\left(\mathrm{H}^{+}\right): 304.1292$; found: 304.1291 .

(1-Isopropyl-1H-1,2,3-triazol-4-yl)methyl (E)-3-(3,4-dihydroxyphenyl)acrylate 12d. 2-Bromopropane (11d) (96.81 $\mu \mathrm{l}$, $1.03 \mathrm{mmol}), \mathrm{NaN}_{3}(72.32 \mathrm{mg}, 1.11 \mathrm{mmol}), 6 \quad(155.78 \mathrm{mg}$, $0.71 \mathrm{mmol}), \quad \mathrm{CuSO}_{4} \cdot 5 \mathrm{H}_{2} \mathrm{O} \quad(57.31 \mathrm{mg}, \quad 0.23 \mathrm{mmol})$, and sodium ascorbate $(19.14 \mathrm{mg}, 0.10 \mathrm{mmol})$. A white solid is obtained after flash chromatography (EtOAc/hexane $50: 50$ ). Yield: $117.3 \mathrm{mg}$ (54\%); $R_{f}=0.11$ (EtOAc/hexane $50: 50$ ); m.p. $=50-55^{\circ} \mathrm{C}$; IR $\left(\nu\left(\mathrm{cm}^{-1}\right)\right): 3376\left(\mathrm{C}_{\mathrm{ar}} \mathrm{O}-\mathrm{H}\right), 2930\left(\mathrm{C}_{\mathrm{sp} 3}-\mathrm{H}\right)$, $1693(\mathrm{C}=\mathrm{O}), 1633-1440(\mathrm{C}=\mathrm{C}), 1285,1162(\mathrm{C}-\mathrm{O}) ;{ }^{1} \mathrm{H}$ NMR (400 MHz, DMSO-d $\left.{ }_{6}, 25^{\circ} \mathrm{C}\right), \delta(\mathrm{ppm}): 9.61\left(\mathrm{~s}, 1 \mathrm{H}, \mathrm{C}_{\mathrm{ar}} \mathrm{OH}\right)$, $9.14\left(\mathrm{~s}, 1 \mathrm{H}, \mathrm{C}_{\mathrm{ar}} \mathrm{OH}\right), 8.24(\mathrm{~s}, 1 \mathrm{H},=\mathrm{CHN}), 7.53-7.49(\mathrm{~d}, 1 \mathrm{H}, J$ $\left.=15.9 \mathrm{~Hz},=\mathrm{CHC}_{\mathrm{ar}}\right), 7.06-7.00\left(\mathrm{~m}, 2 \mathrm{H}, \mathrm{H}_{\mathrm{ar}}\right), 6.77-6.75(\mathrm{~m}$, $\left.1 \mathrm{H}, \mathrm{H}_{\mathrm{ar}}\right), 6.31-6.27(\mathrm{~d}, 1 \mathrm{H}, J=15.9 \mathrm{~Hz},=\mathrm{CHCO}), 5.22(\mathrm{~s}, 2 \mathrm{H}$, $-\mathrm{OCH}_{2} \mathrm{C}$ ), 4.86-4.79 (sept, $\left.1 \mathrm{H}, J=6.6 \mathrm{~Hz}, \mathrm{NCH}-\right), 1.50-1.49$ $\left(\mathrm{d}, 6 \mathrm{H}, J=6.7 \mathrm{~Hz},-\left(\mathrm{CH}_{3}\right)_{2}\right) ;{ }^{13} \mathrm{C}$ NMR $\left(100 \mathrm{MHz}, \mathrm{DMSO}-\mathrm{d}_{6}\right.$, $\left.25^{\circ} \mathrm{C}\right), \delta$ (ppm): $166.73,149.00,146.16,146.03,142.34,125.89$, $123.02,121.97,116.18,115.37,113.92,57.55,52.83,23.08$; HRMS $\mathrm{m} / \mathrm{s}$ calc. for $\mathrm{C}_{15} \mathrm{H}_{17} \mathrm{~N}_{3} \mathrm{O}_{4}+\left(\mathrm{H}^{+}\right): 304.1292$; found: 304.1334 .

[1-(3-Methyl-2-butenyl)-1H-1,2,3-triazol-4-yl]methyl (E)-3-(3, 4-dihydroxy phenyl) acrylate 12e. 1-Bromo-3-methyl-2-butene (11e) $(95.30 \mu \mathrm{l}, 0.82 \mathrm{mmol}), \mathrm{NaN}_{3}(79.84 \mathrm{mg}, 1.23 \mathrm{mmol}), 6$ (153.88 mg, $0.71 \mathrm{mmol}$ ), $\mathrm{CuSO}_{4} \cdot 5 \mathrm{H}_{2} \mathrm{O}(46.63 \mathrm{mg}, 0.19 \mathrm{mmol})$, and sodium ascorbate $(18.40 \mathrm{mg}, 0.09 \mathrm{mmol})$. A dark beige solid is obtained after flash chromatography (EtOAc/hexane 40 : 60). Yield: $147.1 \mathrm{mg}$ (63\%); $R_{f}=0.18$ (EtOAc/hexane $50: 50)$; m.p. $=123-126^{\circ} \mathrm{C}$; IR $\left(v\left(\mathrm{~cm}^{-1}\right)\right): 3460\left(\mathrm{C}_{\mathrm{ar}} \mathrm{O}-\mathrm{H}\right)$, $2969\left(\mathrm{C}_{\mathrm{sp} 3}-\mathrm{H}\right), 1702(\mathrm{C}=\mathrm{O}), 1603-1440(\mathrm{C}=\mathrm{C}), 1264,1153(\mathrm{C}-$ O); ${ }^{1} \mathrm{H}$ NMR (400 MHz, DMSO-d $\left.\mathrm{d}_{6}, 25^{\circ} \mathrm{C}\right), \delta$ (ppm): 9.62 $\left(\mathrm{s}, 1 \mathrm{H}, \mathrm{C}_{\mathrm{ar}} \mathrm{OH}\right), 9.14\left(\mathrm{~s}, 1 \mathrm{H}, \mathrm{C}_{\mathrm{ar}} \mathrm{OH}\right), 8.10(\mathrm{~s}, 1 \mathrm{H},=\mathrm{CHN})$, $7.52-7.48\left(\mathrm{~d}, 1 \mathrm{H}, J=15.9 \mathrm{~Hz},=\mathrm{CHC}_{\mathrm{ar}}\right), 7.05-7.00(\mathrm{~m}, 2 \mathrm{H}$, $\left.\mathrm{H}_{\mathrm{ar}}\right), 6.77-6.75\left(\mathrm{~m}, 1 \mathrm{H}, \mathrm{H}_{\mathrm{ar}}\right), 6.30-6.26(\mathrm{~d}, 1 \mathrm{H}, J=15.9 \mathrm{~Hz}$, $=\mathrm{CHCO}), 5.43-5.40\left(\mathrm{~m}, 1 \mathrm{H},-\mathrm{CHC}\left(\mathrm{CH}_{3}\right)_{2}\right), 5.22(\mathrm{~s}, 2 \mathrm{H}$, $\left.-\mathrm{OCH}_{2} \mathrm{C}\right), 4.99-4.97\left(\mathrm{~d}, 2 \mathrm{H}, J=7.3 \mathrm{~Hz}, \mathrm{NCH}_{2}-\right), 1.77-1.74(\mathrm{~d}$, $\left.6 \mathrm{H}, J=13.5 \mathrm{~Hz},-\mathrm{C}\left(\mathrm{CH}_{3}\right)_{2}\right) ;{ }^{13} \mathrm{C}$ NMR $(100 \mathrm{MHz}$, DMSO-d 6 , $\left.25^{\circ} \mathrm{C}\right), \delta$ (ppm): $166.73,149.01,146.15,146.03,142.57,138.63$, $125.88,124.69,121.98,118.82,116.18,115.35,113.91,57.48,55.28$, 47.71, 25.76, 18.30; HRMS $m / s$ calc. for $\mathrm{C}_{17} \mathrm{H}_{20} \mathrm{~N}_{3} \mathrm{O}_{4}+\left(\mathrm{H}^{+}\right)$: 330.1448; found: 330.1419 .

(1-Hexyl-1H-1,2,3-triazol-4-yl)methyl (E)-3-(3,4-dihydroxyphenyl)acrylate 12f. 1-Chlorohexane (11f) $(100 \mu \mathrm{l}, 0.73 \mathrm{mmol})$, $\mathrm{NaN}_{3} \quad(52.12 \mathrm{mg}, \quad 0.80 \mathrm{mmol}), \quad 6 \quad(155 \mathrm{mg}, 0.71 \mathrm{mmol})$, $\mathrm{CuSO}_{4} \cdot 5 \mathrm{H}_{2} \mathrm{O}(37.26 \mathrm{mg}, 0.15 \mathrm{mmol})$, and sodium ascorbate $(15.37 \mathrm{mg}, 0.078 \mathrm{mmol})$. A brown solid is obtained after flash chromatography (EtOAc/hexane 40:60). Yield: $53.6 \mathrm{mg}$ (22\%); $R_{f}=0.20($ EtOAc/hexane $50: 50) ;$ m.p. $=51-55^{\circ} \mathrm{C}$; IR $\left(\nu\left(\mathrm{cm}^{-1}\right)\right): 3500-3000\left(\mathrm{C}_{\mathrm{ar}} \mathrm{O}-\mathrm{H}\right), 2924,2855\left(\mathrm{C}_{\mathrm{sp} 3}-\mathrm{H}\right)$, $1702(\mathrm{C}=\mathrm{O}), 1598-1440(\mathrm{C}=\mathrm{C}), 1257,1149$ (C-O); ${ }^{1} \mathrm{H}$ NMR $\left(400 \mathrm{MHz}, \mathrm{DMSO}-\mathrm{d}_{6}, 25^{\circ} \mathrm{C}\right), \delta(\mathrm{ppm}): 9.63\left(\mathrm{~s}, 1 \mathrm{H}, \mathrm{C}_{\mathrm{ar}} \mathrm{OH}\right)$, $9.17\left(\mathrm{~s}, 1 \mathrm{H}, \mathrm{C}_{\mathrm{ar}} \mathrm{OH}\right), 8.18(\mathrm{~s}, 1 \mathrm{H},=\mathrm{CHN}), 7.52-7.48(\mathrm{~d}, 1 \mathrm{H}, J$ $\left.=15.9 \mathrm{~Hz},=\mathrm{CHC}_{\mathrm{ar}}\right), 7.05-6.99\left(\mathrm{~m}, 2 \mathrm{H}, \mathrm{H}_{\mathrm{ar}}\right), 6.78-6.72(\mathrm{~m}$, $\left.1 \mathrm{H}, \mathrm{H}_{\mathrm{ar}}\right), 6.31-6.26(\mathrm{~d}, 1 \mathrm{H}, J=15.9 \mathrm{~Hz},=\mathrm{CHCO}), 5.22(\mathrm{~s}, 2 \mathrm{H}$, $\left.-\mathrm{OCH}_{2} \mathrm{C}\right), 4.37-4.33\left(\mathrm{t}, 2 \mathrm{H}, J=7.1 \mathrm{~Hz}, \mathrm{NCH}_{2} \mathrm{C}\right), 1.84-177$ (quint, $\left.2 \mathrm{H}, J=7.2 \mathrm{~Hz}, \mathrm{CCH}_{2} \mathrm{C}\right), 1.25-1.21\left(\mathrm{~m}, 6 \mathrm{H}, \mathrm{H}_{\mathrm{sp} 3}\right)$, $0.86-0.83\left(\mathrm{t}, 3 \mathrm{H}, J=6.7 \mathrm{~Hz},-\mathrm{CCH}_{3}\right) ;{ }^{13} \mathrm{C}$ NMR $(100 \mathrm{MHz}$, DMSO $\left.^{-\mathrm{d}_{6}}, 25^{\circ} \mathrm{C}\right), \delta$ (ppm): $166.73,149.00,146.14,146.03$, $142.46,125.87,125.07,121.99,116.18,115.30,113.92,57.50$, 49.82, 31.00, 30.08, 25.93, 22.36, 14.28; HRMS $\mathrm{m} / \mathrm{s}$ calc. for $\mathrm{C}_{19} \mathrm{H}_{17} \mathrm{~N}_{3} \mathrm{O}_{4}+\left(\mathrm{H}^{+}\right): 346.1761$; found: 346.1764 .

[1-(2-Cyclohexylethyl)-1H-1,2,3-triazol-4-yl]methyl (E)-3-(3,4dihydroxy phenyl) acrylate 12g. 1-(2-Bromoethyl)cyclohexane (11g) $(108 \mu \mathrm{l}, 0.69 \mathrm{mmol}), \mathrm{NaN}_{3}(55.15 \mathrm{mg}, 0.85 \mathrm{mmol})$, $6 \quad(152.30 \mathrm{mg}, \quad 0.70 \mathrm{mmol}), \quad \mathrm{CuSO}_{4} \cdot 5 \mathrm{H}_{2} \mathrm{O} \quad(59.72 \mathrm{mg}$, $0.24 \mathrm{mmol})$, and sodium ascorbate $(20.80 \mathrm{mg}, 0.10 \mathrm{mmol})$. A pale yellow solid is obtained after flash chromatography $($ EtOAc/hexane $40: 60)$. Yield $=131.8 \mathrm{mg}(51 \%) ; R_{f}=0.19$ $\left(\right.$ EtOAc/hexane 50:50); m.p. $=66-72^{\circ} \mathrm{C}$; IR $\left(\nu\left(\mathrm{cm}^{-1}\right)\right)$ : $3356\left(\mathrm{C}_{\mathrm{ar}} \mathrm{O}-\mathrm{H}\right), 2924,2853\left(\mathrm{C}_{\mathrm{sp} 3}-\mathrm{H}\right), 1687(\mathrm{C}=\mathrm{O}), 1600-1443$ $(\mathrm{C}=\mathrm{C}), 1292,1160(\mathrm{C}-\mathrm{O}) ;{ }^{1} \mathrm{H}$ NMR $\left(400 \mathrm{MHz}, \mathrm{CD}_{3} \mathrm{OD}\right.$, $\left.25^{\circ} \mathrm{C}\right), \delta(\mathrm{ppm}): 8.04(\mathrm{~s}, 1 \mathrm{H},=\mathrm{CHN}), 7.61-7.57(\mathrm{~d}, 1 \mathrm{H}, J=$ $\left.15.9 \mathrm{~Hz},=\mathrm{CHC}_{\mathrm{ar}}\right), 7.05-6.78\left(\mathrm{~m}, 3 \mathrm{H}, \mathrm{H}_{\mathrm{ar}}\right), 6.30-6.23(\mathrm{~d}, 1 \mathrm{H}$, $J=15.9 \mathrm{~Hz},=\mathrm{CHCO}), 5.30\left(\mathrm{~s}, 2 \mathrm{H}, \mathrm{OCH}_{2} \mathrm{C}=\right), 4.47-4.43(\mathrm{t}$, $\left.2 \mathrm{H}, J=7.4 \mathrm{~Hz}, \mathrm{NCH}_{2} \mathrm{C}\right), 2.03-1.01\left(\mathrm{~m}, 13 \mathrm{H}, \mathrm{H}_{\mathrm{sp} 3}\right) ;{ }^{13} \mathrm{C} \mathrm{NMR}$ $\left(100 \mathrm{MHz}, \mathrm{CD}_{3} \mathrm{OD}, 25^{\circ} \mathrm{C}\right), \delta$ (ppm): $167.26,148.33,146.10$, $145.43,142.81,126.21,124.28,121.66,115.09,113.75,113.15$, $56.73,47.93,37.31,34.77,32.54,26.08,25.81$; HRMS $\mathrm{m} / \mathrm{s}$ calc. for $\mathrm{C}_{19} \mathrm{H}_{17} \mathrm{~N}_{3} \mathrm{O}_{4}+\left(\mathrm{H}^{+}\right)$: 372.1918; found: 372.1922 .

\subsection{5-LO Product Biosynthesis Inhibition Assays}

4.2.1. 5-LO Products Biosynthesis Inhibition in HEK293 Cells. HEK293 cells stably cotransfected with a pcDNA3.1 vector expressing human 5-LO and a pBUDCE4.1 vector expressing human 5-LO activating protein (FLAP) were utilized $[15,20]$ to screen compounds for 5-LO inhibition.

For cell stimulation of 5-LO products, transfected HEK293 cells were collected following trypsinization and washed and the cell pellet was resuspended in Hank's balanced salt solution (HBSS) (Lonza, Walkerville, MD) containing $1.6 \mathrm{mM} \mathrm{CaCl}_{2}$ at a concentration of $5 \times 10^{5}$ cells $\mathrm{mL}^{-1}$. Cells were preincubated with each test compound at $1 \mu \mathrm{M}$ for $5 \mathrm{~min}$ at $37^{\circ} \mathrm{C}$. Cells were then stimulated for 15 minutes at $37^{\circ} \mathrm{C}$ with the addition of $10 \mu \mathrm{M}$ calcium ionophore A23187 (Sigma-Aldrich, Oakville, ON, Canada) and $10 \mu \mathrm{M}$ arachidonic acid (Cayman Chemical, Ann Arbour, MI). Stimulations were stopped by the addition of 0.5 volume of cold $\mathrm{MeOH}: \mathrm{CH}_{3} \mathrm{CN}(1: 1)$ containing $50 \mathrm{ng}$ of $\mathrm{PGB}_{2}$ as internal standard and samples were stored at $-20^{\circ} \mathrm{C}$ until processing on octadecyl (C18) columns and analysis by RPHPLC as described previously $[15,20]$. Data are expressed as 
means \pm SEM of 3 independent experiments, each performed in duplicate (Figures 3-5).

4.2.2. 5-LO Products Biosynthesis Inhibition in PMNL Cells $P M N L$. Human PMNL prepared from peripheral blood as described [11] were suspended in HBSS containing $1.6 \mathrm{mM}$ $\mathrm{CaCl}_{2}\left(10^{7}\right.$ cells $\left./ \mathrm{ml}\right)$ and preincubated with test compounds for $5 \mathrm{~min}$ at $37^{\circ} \mathrm{C}$ in the presence of $0.4 \mathrm{U} / \mathrm{ml}$ of adenosine deaminase (Sigma-Aldrich, Oakville, On, Canada). Cells were then stimulated for $15 \mathrm{~min}$ at $37^{\circ} \mathrm{C}$ with $1 \mu \mathrm{M}$ thapsigargin (Sigma-Aldrich) and $10 \mu \mathrm{M}$ AA (Cayman Chemical, Ann Arbour, MI) as previously described [11]. Reactions were stopped, processed, and analyzed by RP-HPLC as indicated above. Data are expressed as means \pm SEM of 3 independent experiments, each performed in duplicate (Figure 6).

4.3. Molecular Docking. Molecular docking was performed with AutoDock Vina 1.1.2 on 5-LO (PDB code: 3O8Y) following the procedure [17] outlined in "Design, Synthesis and Evaluation of Semi-Synthetic Triazole-Containing Caffeic Acid Analogs as 5-Lipoxygenase Inhibitors" by Daniela De Lucia et al. For optimization, the MMFF94 force field was used. Results were analyzed with Maestro 11.0 [21].

\section{Conflicts of Interest}

The authors declare that there are no conflicts of interest regarding the publication of this paper.

\section{Acknowledgments}

Mohamed Touaibia would like to acknowledge the contribution of the Natural Sciences and Engineering Research Council of Canada (NSERC), the New Brunswick Innovation Foundation (NBIF), the Canadian Foundation for Innovation (CFI), and Université de Moncton. Marc E. Surette is supported by a New Brunswick Innovation Research Chair awarded by the NBIF.

\section{References}

[1] W. R. Henderson Jr., "The role of leukotrienes in inflammation," Annals of Internal Medicine, vol. 121, no. 9, pp. 684-697, 1994.

[2] C. Pergola and O. Werz, "5-Lipoxygenase inhibitors: a review of recent developments and patents," Expert Opinion on Therapeutic Patents, vol. 20, no. 3, pp. 355-375, 2010.

[3] O. Kowal-Bielecka, K. Kowal, O. Distler, and S. Gay, "Mechanisms of disease: leukotrienes and lipoxins in scleroderma lung disease-insights and potential therapeutic implications," Nature Clinical Practice Rheumatology, vol. 3, no. 1, pp. 43-51, 2007.

[4] J. N. Sharma and L. A. Mohammed, "The role of leukotrienes in the pathophysiology of inflammatory disorders: is there a case for revisiting leukotrienes as therapeutic targets?" Inflammopharmacology, vol. 14, no. 1-2, pp. 10-16, 2006.

[5] B. Samuelsson, S.-E. Dahlen, J. A. Lindgren, C. A. Rouzer, and C. N. Serhan, "Leukotrienes and lipoxins: structures, biosynthesis, and biological effects," Science, vol. 237, no. 4819, pp. 1171-1176, 1987.
[6] E. Israel, J. Cohn, L. Dubé, and J. M. Drazen, "Effect of treatment with zileuton, a 5-lipoxygenase inhibitor, in patients with asthma: a randomized controlled trial," Journal of the American Medical Association, vol. 275, no. 12, pp. 931-936, 1996.

[7] O. Werz and D. Steinhilber, "Therapeutic options for 5-lipoxygenase inhibitors," Pharmacology \& Therapeutics, vol. 112, no. 3, pp. 701-718, 2006.

[8] A. S. Fischer, J. Metzner, S. D. Steinbrink et al., "5-Lipoxygenase inhibitors induce potent anti-proliferative and cytotoxic effects in human tumour cells independently of suppression of 5lipoxygenase activity," British Journal of Pharmacology, vol. 161, no. 4, pp. 936-949, 2010.

[9] J. Ghosh and C. E. Myers, "Inhibition of arachidonate 5lipoxygenase triggers massive apoptosis in human prostate cancer cells," Proceedings of the National Academy of Sciences of the United States of America, vol. 95, no. 22, pp. 13182-13187, 1998.

[10] A.-P. Beauregard, J. Harquail, G. Lassalle-Claux et al., "CAPE analogs induce growth arrest and apoptosis in breast cancer cells," Molecules, vol. 20, no. 7, pp. 12576-12589, 2015.

[11] Jérémie A. Doiron, Luc M. Leblanc, Martin J. G. Hébert et al., "Structure activity relationship of caffeic acid phenethyl ester analogs as new 5-lipoxygenase inhibitors," Chemical Biology \& Drug Design, vol. 89, no. 4, pp. 514-528, 2017.

[12] L. H. Boudreau, J. Maillet, L. M. LeBlanc et al., "Caffeic acid phenethyl ester and its amide analogue are potent inhibitors of leukotriene biosynthesis in human polymorphonuclear leukocytes," PLoS ONE, vol. 7, no. 2, Article ID e31833, 2012.

[13] D. De Lucia, O. M. Lucio, B. Musio et al., "Design, synthesis and evaluation of semi-synthetic triazole-containing caffeic acid analogues as 5-lipoxygenase inhibitors," European Journal of Medicinal Chemistry, vol. 101, pp. 573-583, 2015.

[14] E. M. Joshi, B. H. Heasley, M. D. Chordia, and T. L. Macdonald, "In vitro metabolism of 2-acetylbenzothiophene: relevance to zileuton hepatotoxicity," Chemical Research in Toxicology, vol. 17, no. 2, pp. 137-143, 2004.

[15] L. H. Boudreau, N. Picot, J. Doiron et al., "Caffeoyl and cinnamoyl clusters with anti-inflammatory and anti-cancer effects. Synthesis and structure-activity relationship," New Journal of Chemistry, vol. 33, no. 9, pp. 1932-1940, 2009.

[16] J. A. Doiron, B. Métayer, R. R. Richard et al., "Clicked cinnamic/caffeic esters and amides as radical scavengers and 5-lipoxygenase inhibitors," International Journal of Medicinal Chemistry, vol. 2014, 12 pages, 2014.

[17] C. E. Walsh, B. M. Waite, M. J. Thomas, and L. R. DeChatelet, "Release and metabolism of arachidonic acid in human neutrophils," Journal of Biological Chemistry, vol. 256, no. 14, pp. 7228-7234, 1981.

[18] E. Shang et al., "Benzo[d]isothiazole 1, 1-dioxide derivatives as dual functional inhibitors of 5-lipoxygenase and microsomal prostaglandin E2 synthase-1," Bioorganic \& Medicinal Chemistry Letters, vol. 24, no. 12, pp. 2764-2767, 2014.

[19] N. C. Gilbert, S. G. Bartlett, M. T. Waight et al., "The structure of human 5-lipoxygenase," Science, vol. 331, no. 6014, pp. 217-219, 2011.

[20] J. Doiron, L. H. Boudreau, N. Picot, B. Villebonet, M. E. Surette, and M. Touaibia, "Synthesis and 5-lipoxygenase inhibitory activity of new cinnamoyl and caffeoylclusters," Bioorganic and Medicinal Chemistry Letters, vol. 19, no. 4, pp. 1118-1121, 2009.

[21] Maestro, Schrödinger Release 2016-4, Maestro, Schrödinger, LLC, New York, NY, USA, 2016. 

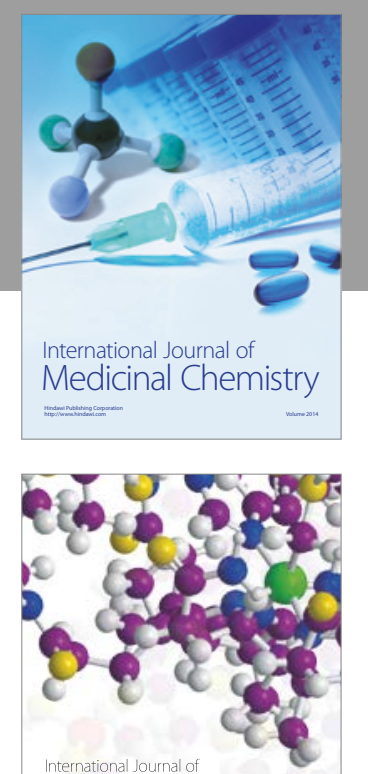

Carbohydrate Chemistry

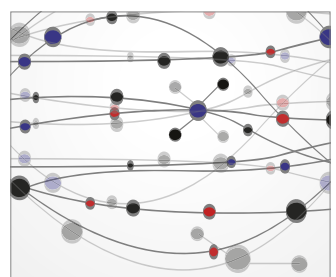

The Scientific World Journal
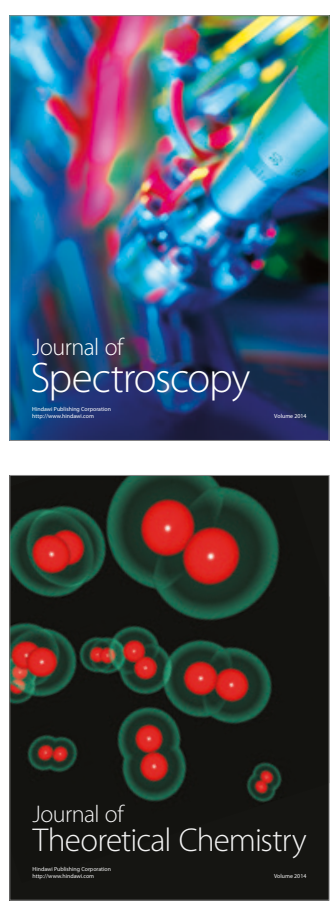
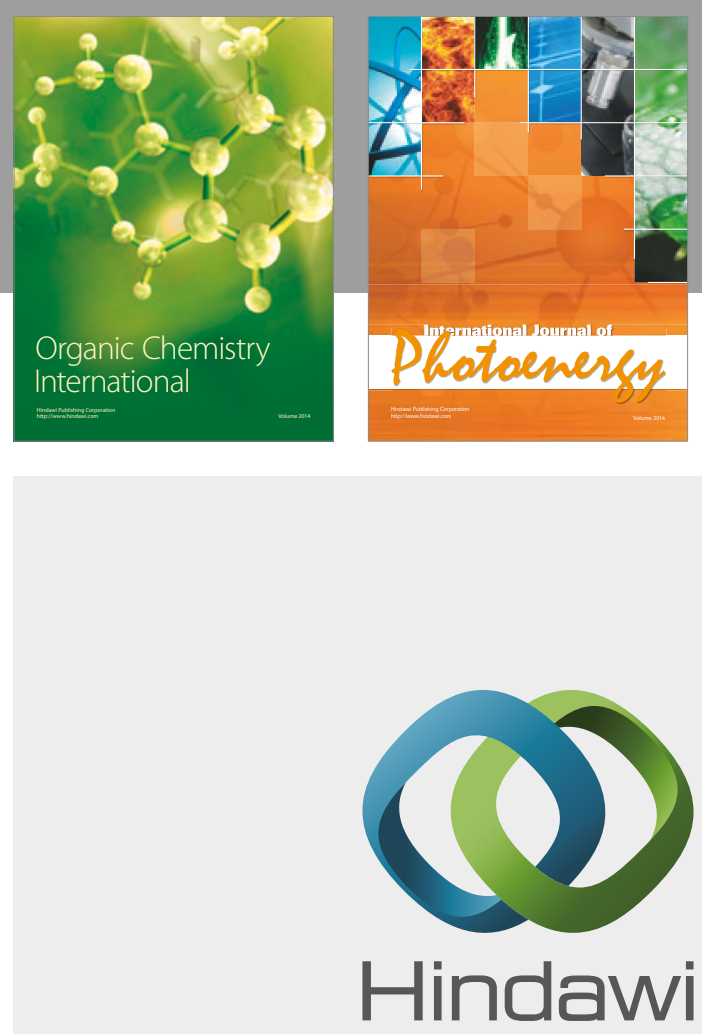

Submit your manuscripts at

https://www.hindawi.com

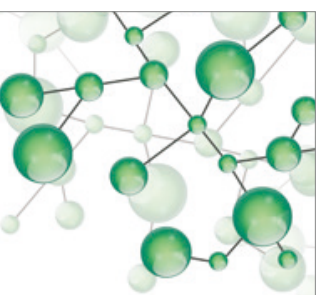

International Journal of

Inorganic Chemistry

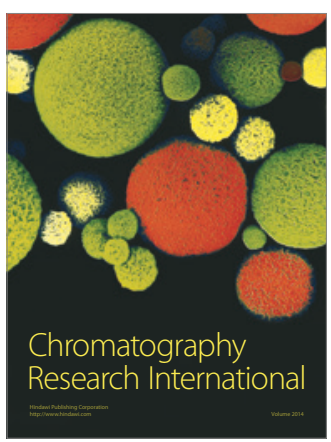

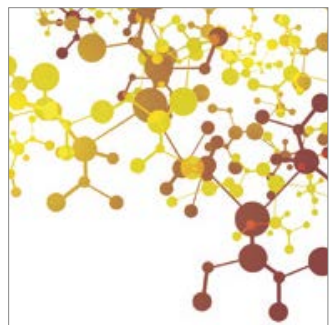

Applied Chemistry
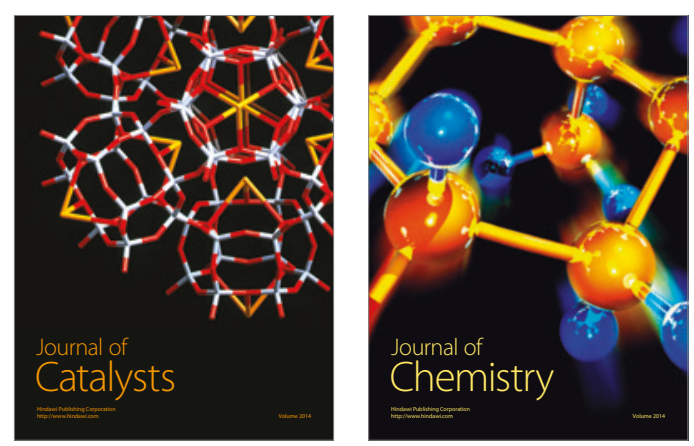
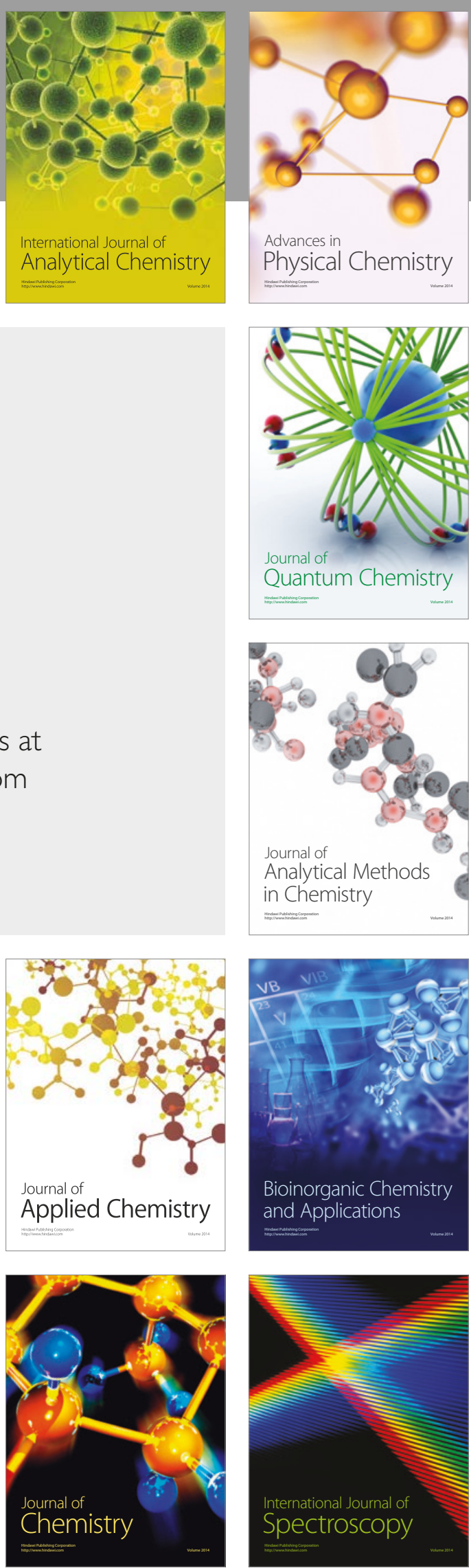